\title{
The Colossus of Rhodes: Some Observations about Its Location ${ }^{1}$
}

\author{
By Robert B. Kebric*
}

This is the first of several interrelated articles on the Colossus of Rhodes submitted to ATINER journals (Kebric 2019a, 2019b). No literary or archaeological evidence exists to demonstrate the configuration or the precise location of the Colossus of Rhodes, one of the Seven Wonders of the Ancient World. The result has been a variety of recreations over the years, the most enduring placing it high above Rhodes harbor, its legs straddling the entrance. A variety of practical reasons entirely eliminates that possibility, and in this investigation, dealing specifically with its location, the best site for the Colossus was with the other most sacred Rhodian temples and shrines on the highest point of the city's acropolis, on what today is known as Monte Smith. There, it could also most effectively serve one of the busiest harbors in the Mediterranean as a giant light tower for vessels approaching and leaving Rhodes. This study combines relevant ancient literary evidence about the Colossus with observations about humans' most primitive instincts and beliefs concerning their geographical surroundings, their understanding of the movement of heavenly bodies-- most particularly at Rhodes that of its patron deity, Helios, god of the sun-- and other salient contributing factors to reach the most compelling conclusion about the Colossus' location. The latter include geological considerations which were necessary to support the weight of such a huge statue, about 160 feet tall including its pedestal. The apex of Monte Smith is also where the subservient Rhodians would later raise a second, smaller colossal statue in honor of the people of Rome. Numerous photographs and maps complement the study, a presentation at ATINER'S $12^{\text {th }}$ Annual International Conference on Mediterranean Studies (April 15-18, 2019).

The best location for the Colossus of Rhodes, one of the Seven Wonders of the Ancient World, was atop the promontory known today as Monte Smith, once sharing with the Temple of Athena Polias and Zeus Polieus the same circumscribed sacred ground at the limestone apex of the ancient Rhodian acropolis. Common sense dictates that the colossal statue of Helios, god of the sun and patron of the island of Rhodes, was placed near the precinct of city guardians Athena and Zeus on the most hallowed walled heights of the city for all to see. It would not have been "buried" somewhere below in the streets, buildings, markets, and harbors-- or on a lower plateau of the acropolis, sloping inward toward the city and described as theater-like (Diodorus 19.45.3), only to restrict Helios from a full day's exposure to his own sunlight.

On less sunny days, such an elevated position also protected the Colossus from the serious flooding that had previously devastated the city ${ }^{2}$ it also placed

\footnotetext{
${ }^{*}$ Senior Professor (Retired), University of Louisville, USA.

1. All photos, unless otherwise indicated, are the property of the author. Maps 1 and 2, as far as can be determined, are public domain. Figure N.2. follows Google's instructions for use.
} 
the giant statue in the less enviable but more practical position of drawing the countless lightning bolts, flung by nearby neighbor Zeus, to its body. Had the colossal monument been erected within the urban precinct, ${ }^{3}$ the collateral damage from such strikes, probably numbering in the hundreds over its brief lifespan, would have been insufferable. ${ }^{4}$ Standing atop the acropolis heights and in an open precinct not far from Zeus' own temple, the Colossus' positioning on Monte Smith at least confined the bolts to these two deities, who were both closely linked by tradition to solar mythology. ${ }^{5}$

Clearly, lightning strikes were a problem the creators of the Colossus would have to have considered from the start, and the only practical solution to constructing what would also be the Greek world's greatest "lightning rod," was to place it in an area where the least accompanying damage might be suffered. That would not have been in the city- but high above it, on Monte Smith.

From the crowning elevation of the acropolis, the Colossus of Rhodes could be seen standing magnificently by itself (see Figure 1) - distinct from the numerous other "colossal" statues, including gods, which Pliny the Elder says (34.18.42) embellished the city at the same time. At about 160 feet

2. E.g. Diodorus, History, 19.45.3-8.

3. Sven Schipporeit has presented a very interesting and precise study of the public and sacred spaces in ancient Rhodes, also including Hoepfner and Schwandler's 1994 map of the ancient city and other helpful insights, in, "The New Order of Time and Cult in Synoecized Poleis," Center for Hellenic Studies (CHS) Research Bulletin 4, no.2 (2016), at www.chsfellows.org/2016/11/01/new-order-of-time-and-cult.

4. The Statue of Liberty, often compared to the Colossus, is, at least according to The Telegraph (May 3, 2017, "Statue of Liberty (\#31)": www.telegraph.co.uk), struck by as many as 600 lightning bolts a year. Other on-line sources place them in the hundreds. The different location of the Colossus and weather conditions would, of course, negate any direct comparisons, but the statistic is still indication enough that it, too, would often have been struck by lightning. In 2010, a photographer captured a lightning bolt hitting the Statue of Liberty, an impressive moment which can be seen at several on-line sources (e.g. www.dailymail.com.co.uk., October 12, 2010). The same Telegraph article mentioned above also states that Liberty can sway up to three inches in winds of $50 \mathrm{mph}$ or more-- her torch as much as 5 inches. As often pointed out, the basic height of both the Liberty and the Colossus is similar, as is the ultimate elevation of the two statues (including their pedestals-- and, in the case of the Colossus, its location atop Monte Smith at Rhodes), so a general comparison can probably be made as to the effects of strong winds on both. Chares of Lindos (Rhodes), who designed and built the Colossus, would have to have had such natural conditions in mind. Once completed, repairs to the giant statue must also have been a constant concern. Pliny says (Natural History, 34.17.40) that Chares' teacher, the famous sculptor, Lysippus, insured the stability of his 60-foot statue of Zeus at Tarentum with an independent "column" to make sure it could not be dislodged, especially by high winds. There is no reason to suppose that Chares, constructing a statue, some 50 feet higher, would not have taken the same precaution. Thus, a large, separately supported buttress can likewise be confidently proposed for the Colossus, hopefully more artistically incorporated into the Colossus' final stance. Such an independent support(s) also needs to be considered when discussing the Colossus' collapse in the earthquake of c.226 B.C.

5. Arthur Cook's sections on "Zeus in relation to the Sun," "The Sun as the Eye of Zeus," and "Cult-epithets of Zeus that may be Solar," from his 1914 Cambridge work, Zeus: A Study in Ancient Religion (Band 1), 186-196, remain useful in identifying Zeus' early connections with the sun. 
(including pedestal), ${ }^{6}$ it would have towered over everything. Visible from the sea and as far inland and along the island's coasts as the physical environment and clearness of day allowed, the site likewise provided (Figures 2-7) a view of the largest Greek statue ever built and the most dominating human-made feature on the island. It truly was a "Wonder," as Helios gazed unperturbed, "Not only over the seas but also on land."

6. We have elsewhere fully discussed the heights of the colossus and its pedestal (Kebric 2019a), but space restrictions prevent its inclusion here. In brief, Philo of Byzantium, Strabo, and Pliny the Elder, our remaining ancient authorities mentioning the height of the Colossus, all basically agree that it was 70 cubits tall. The problem lies in correctly converting the cubit into feet. Just as the measurement varied slightly among the different societies in antiquity, it has likewise resulted in different opinions today that mostly range between 105-120 feet for 70 cubits. Posidippus $(\mathrm{AB} 68=\mathrm{C}$. Austin and G. Bastianini, eds.), an epigramist contemporary with the Colossus, states that the people of Rhodes urged Chares to make it as tall as he possibly could-- evidence which would seem to favor the extreme end of the range. However, if Chares was not using the same length cubit as modern authorities who arrive at that height did, then the Colossus would not have been that tall. Conversely, Chares may have used a personal version of the measurement (perhaps even the distance between his own elbow and middle figure), resulting in his statue being even taller than 120 feet. There is just no way to reconcile all the different heights, so, for simplicity's sake, we use here a 110-foot measurement for the Colossus. An even more problematic situation exists for the height of the Colossus' pedestal. There was a pedestal, but the only semblance of its height is provided by Philo, a contemporary, who says that the soles of the feet of the Colossus set on its base were already higher than other statues. However, what Philo appears to be describing is the plinth on which the statue immediately stands and not its pedestal, since the lower legs and feet of the Colossus would necessarily have been secured internally by "supports" of stone and/or iron, which would have to have extended much deeper into a pedestal than what Philo describes. Consequently, modern ideas about the pedestal range from 20-50 feet. We will use 50 feet as the most probable height for the Colossus' pedestal because it would not only secure the supports needed to keep the Colossus standing on its pedestal, but also because it would be the same height as the towers on the walls of Rhodes - in order that it could be seen in its entirety behind them. We also accept the suggestion of a three-tiered, no mortar, pedestal for the Colossus, which more recent earthquake studies indicate was the usual construction in antiquity for large architectural bases in earth-quake ridden country - Rhodes included. Finally, in respect to the height of Monte Smith on which we place the Colossus, several topographical studies of Rhodes (e.g., topographic-map.com: Rhodes, Greece) make it to be around 270 feet by today's standards. Whether or not this was also the height over 2,000 years ago is impossible to know, considering all the natural and human-made destruction that has occurred there over the centuries-- as well as changes in the sea-level, if any, below. Hence, "a number close to 300 feet," or a similar phrase, has been used here to describe the height throughout this study. The reader can make the appropriate judgments.

7. Hermann Beckby, Anthologia Graeca, 4, 171 (Munich, 1957), possibly part of the original dedicatory inscription for the Colossus. 


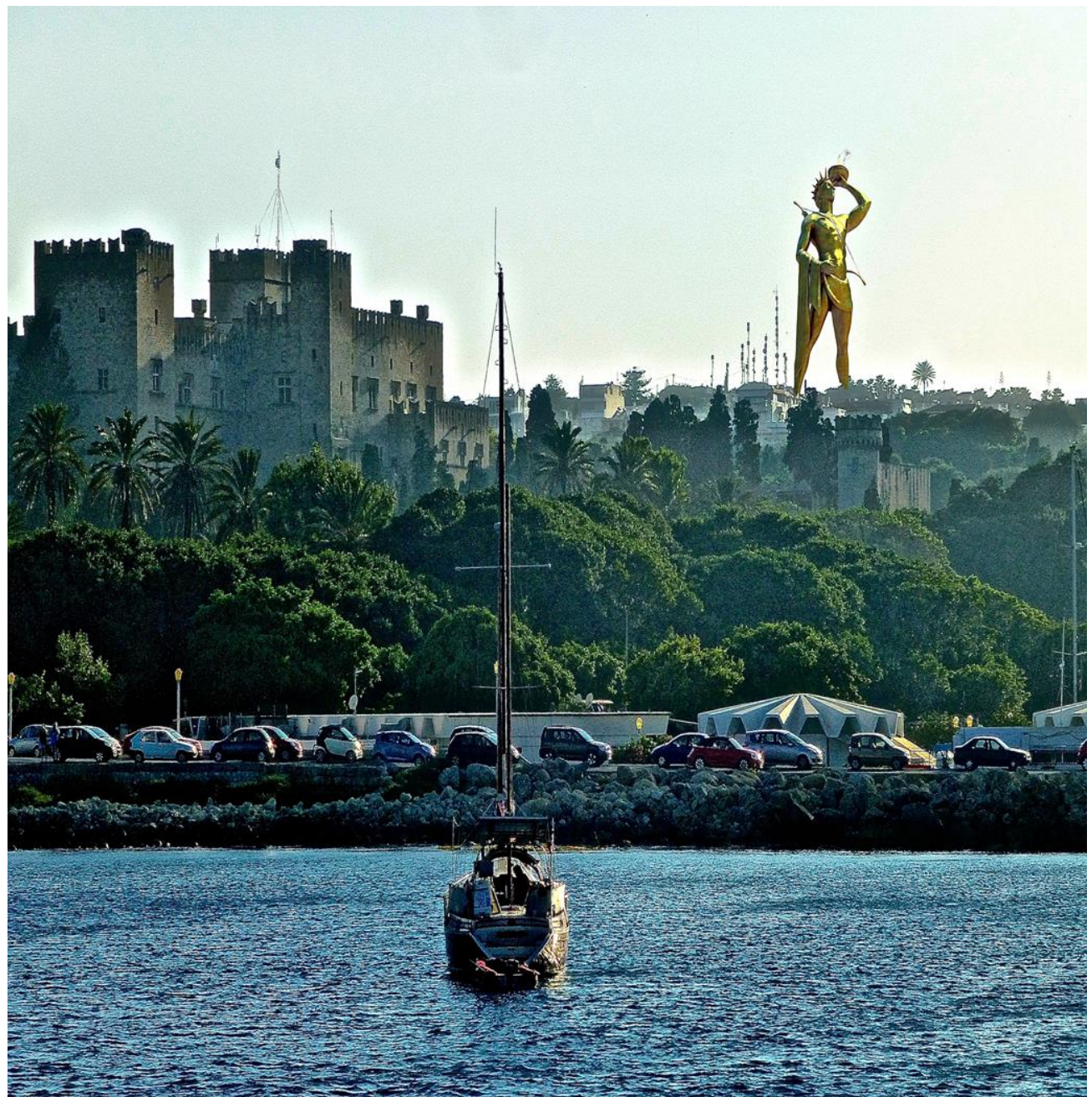

Figure 1. A composite photo in a modern setting at Rhodes, showing how the Colossus (a random image selected for illustration purposes, which, while reflecting the statue's actual height, is not meant to be an accurate representation of its stance or configuration) would have dominated the city and harbors below-- if, as proposed here, it was once located atop Monte Smith.

Although there is nothing definitive known about the Colossus-- an impossibility because it no longer exists-- some tantalizing and relatively sound observations can still be offered, particularly about its location (Figures 2-7). Such insights extend only as far as to how the simplest early observations about the sun and other happenings at Rhodes could have led to traditions being established that later related to the Colossus. Because almost everything said about the Colossus, both ancient and modern, has been much questioned or doubted, a review of past studies will achieve little. What is proposed here is based not only on my own personal experience, but also on what may be reconstructed about the local and international politics affecting Rhodes at the time of the Colossus, as well as a number of other considerations- three of which immediately impact the discussion. 


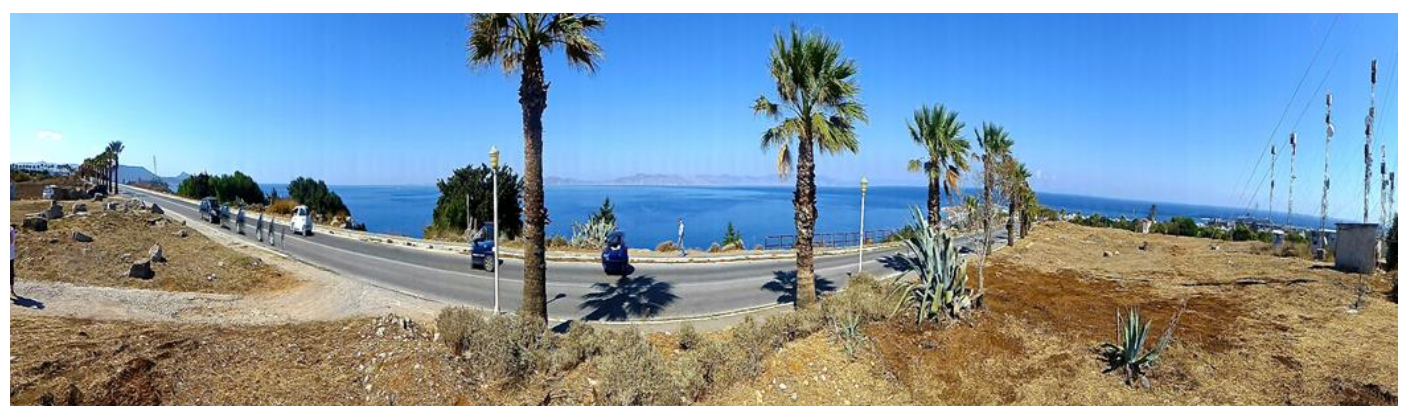

Figure 2.

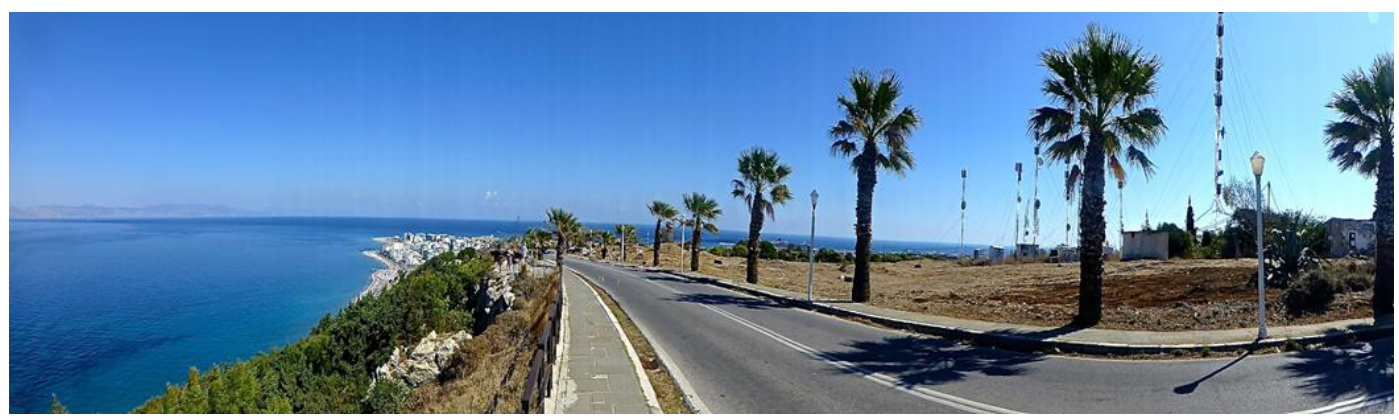

Figure 3.

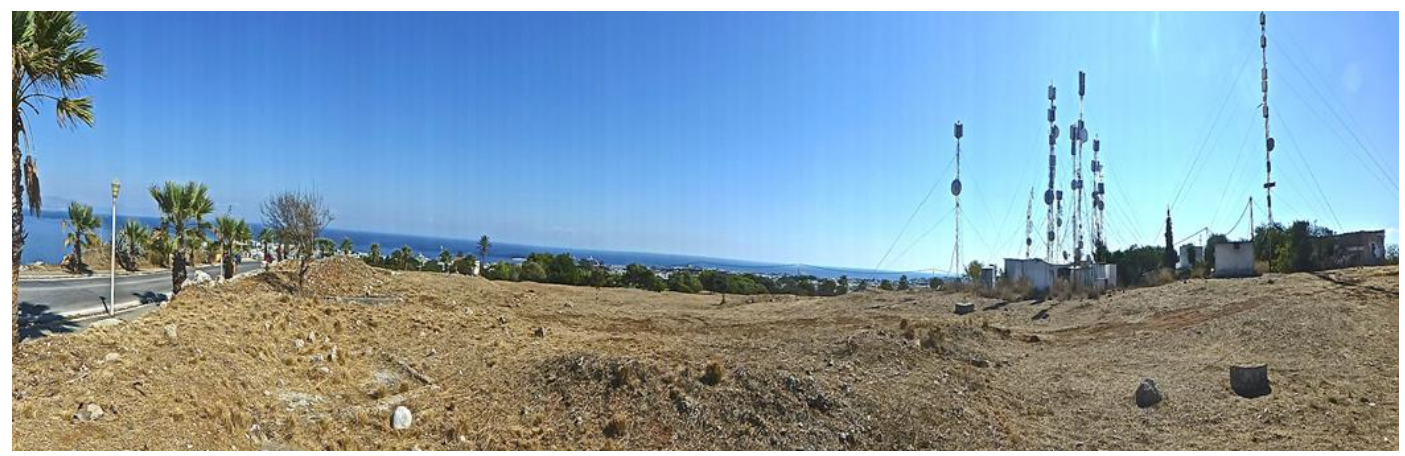

Figure 4.

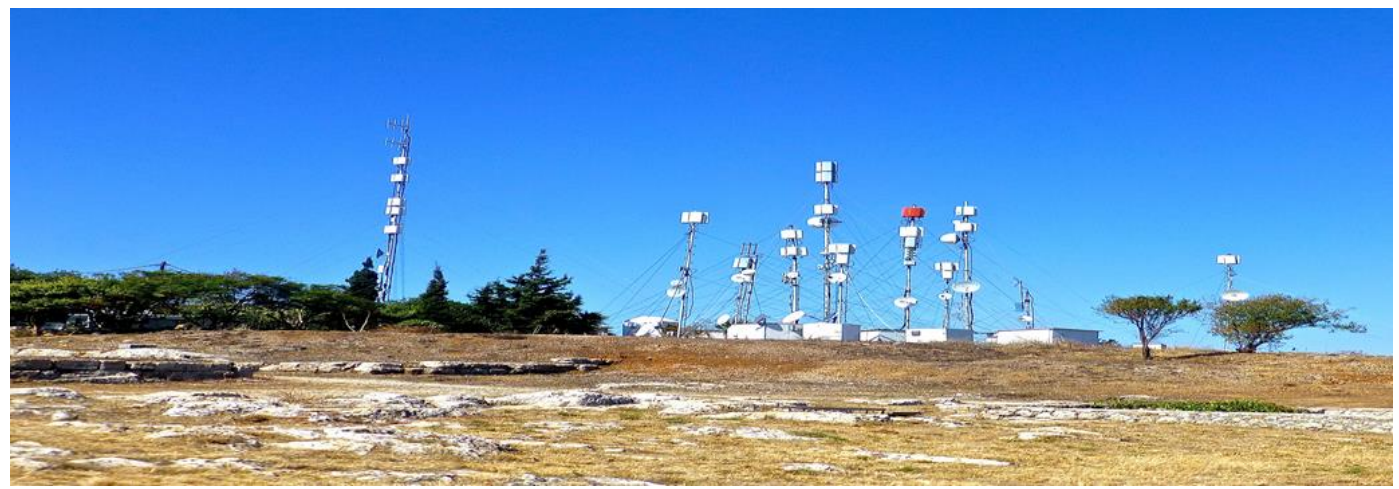

Figure 5. 


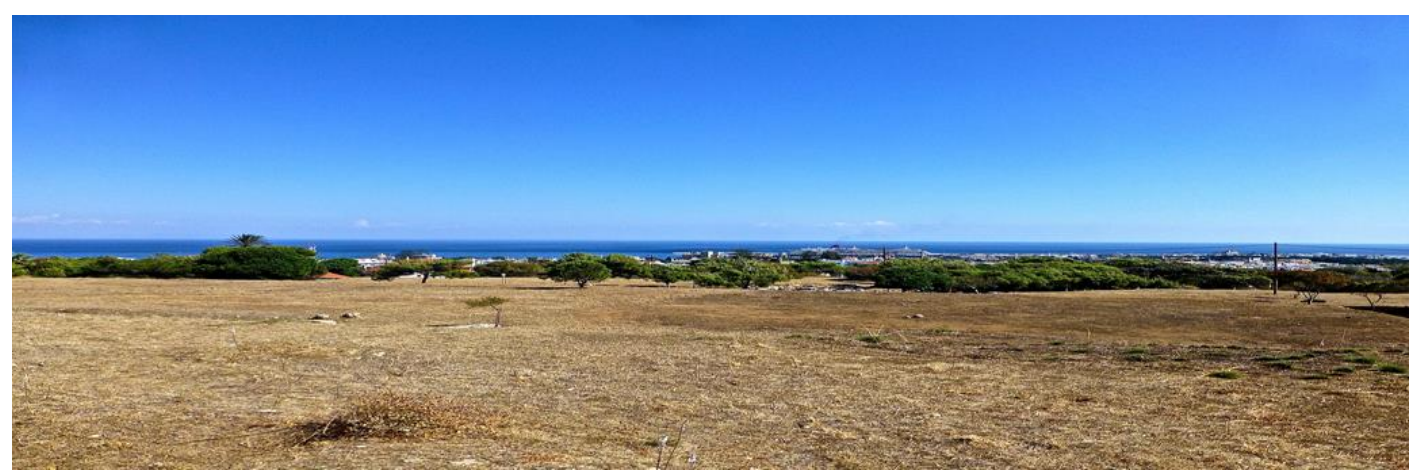

Figure 6.

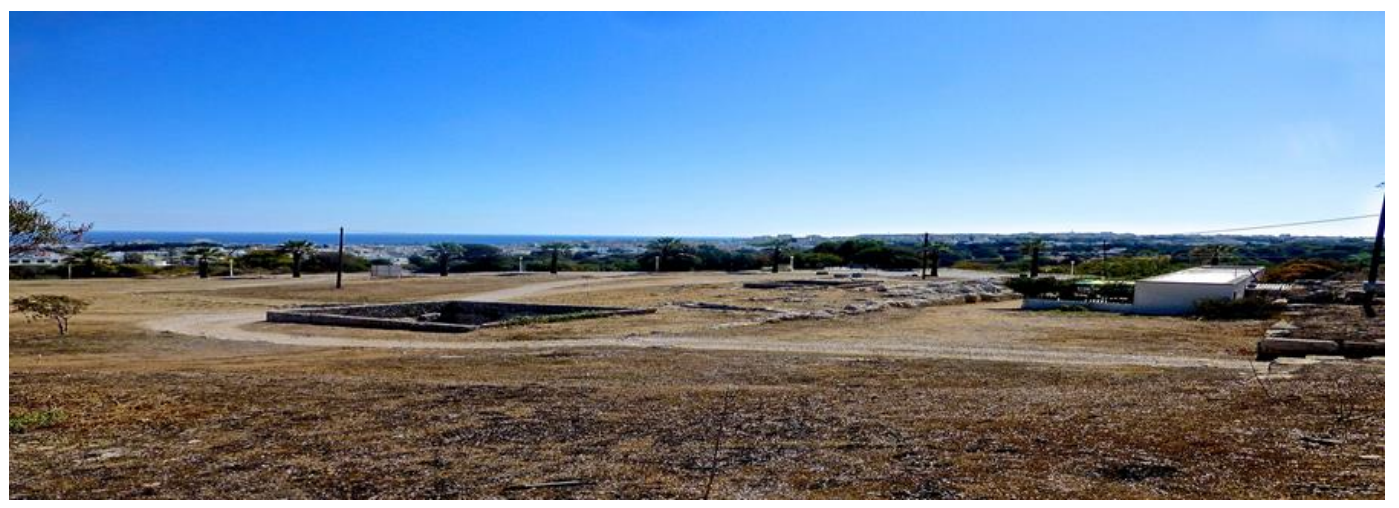

Figure 7. The surrounding environment of Rhodes (Figures 2-7) from the top of Monte Smith, on, or near, the apex of which is the most logical place to have erected the Colossus-and where a 360-degree view of it would have been provided for some miles around. The panorama first moves (2) toward the island's south end (Turkey is across the channel) toward ancient Ialysos and Kamiros, where the mountains leading into the interior of Rhodes can be seen in the distant left corner; proceeds (3) toward the northern tip of the island, where a portion of modern Rhodes City, once the location of one of its five harbors, can be seen; to the peak of Monte Smith (4 and 5), where modern T.V. and cellular towers have been erected, rising up amid remains of the Temple of Athena and Zeus; to the city and cruise ships in the harbor below (6); and back towards the southern part of the island on the opposite, or eastern, seaboard, in the direction of Lindos (including additional remains of ancient structures in the foreground) (7). These views, of course, would be greatly enhanced if photographed from a higher elevation. Nonetheless, they still show how the Colossus, about 160 feet on its pedestal, could have been seen from all directions. See, also, Map 1 of Rhodes, below. 


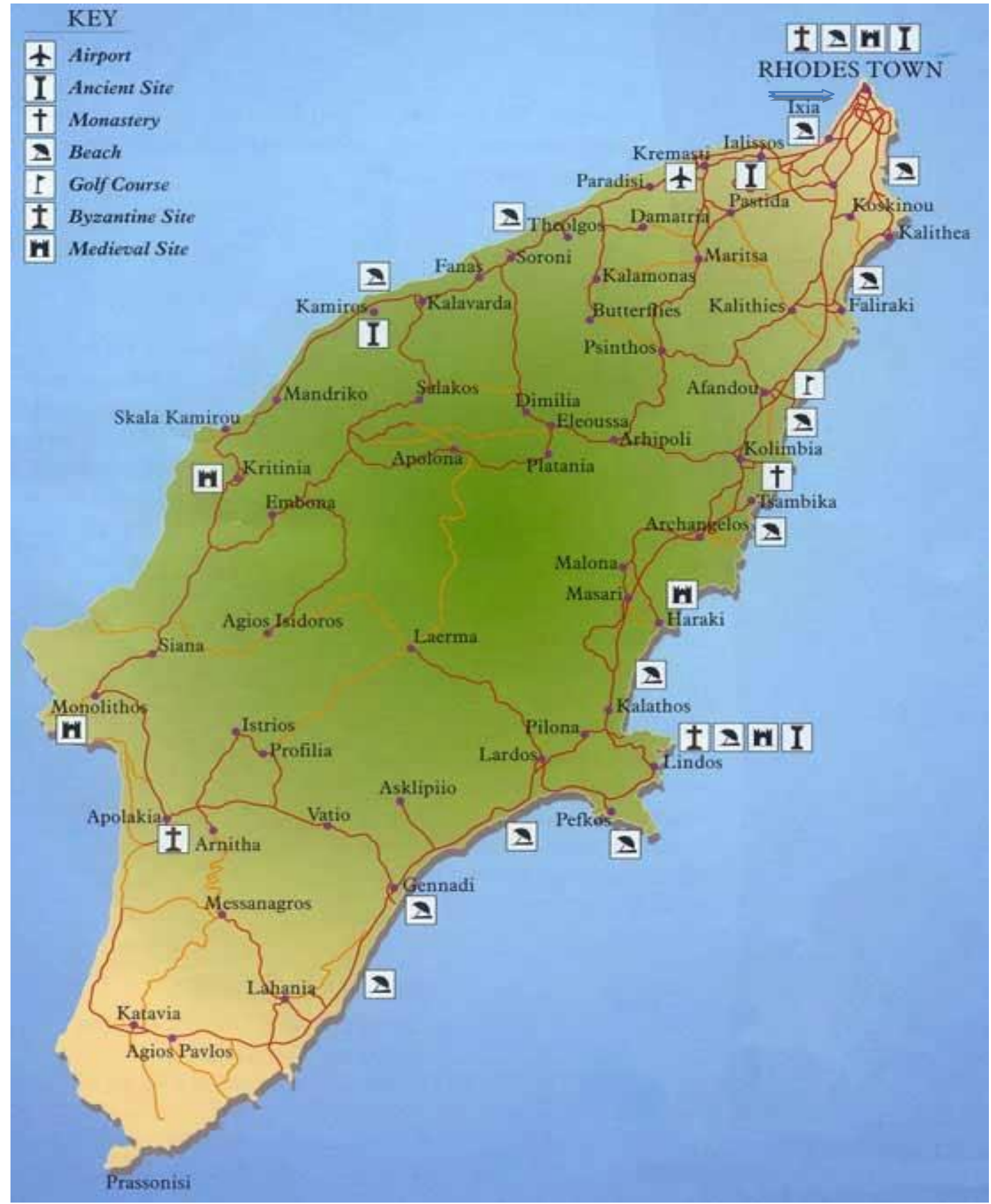

Map 1. Modern Rhodes with key locations. Just below 'Rhodes Town," where the blue arrow points, is Monte Smith-- on which the city's acropolis was once located and the Colossus of Rhodes must have stood-on the left, or western side, close to the island's northern tip. Ixia beach is just below it (see Figure 12).

The first of these considerations concerns the intense interest, some might say obsession, of early humans with tracking the movements of the heavens-particularly the sun and the moon-- and relating their observations to what happened to them on earth. At Rhodes, this fascination relates directly to the 
sun, which especially favored it with, according to some weather services, at least 300 days of sunshine per year. Understandably, the sun's impact on any location, in this case an island, where its seemingly unaltered pattern of movement continually brought light and warmth in abundance, would have immediately attracted the attention of the earliest people. The same sundrenched landscape that annually draws thousands of tourists to Rhodes today, once made it an important early center of sun worship and the place to celebrate its daily renewal of life-- so much so that it was at Rhodes where Helios, the Greek sun god, was made patron deity of the island and the greatest statue ever erected to him was built.

There was, however, something more than the sun's substantial presence at Rhodes. Helios extended his favor even further to demonstrate his special relationship with the island and its people by providing them a chosen place from which they could view his daily movements. From this spot, early observers learned they could watch, without interruption, as the sun rose directly out of the waves of the ocean at sunrise, and, without moving at all, follow his entire arc across the sky until the god in his fiery chariot disappeared into the darkness at the other end of their island in Caria, now Turkey. This place is known today as Monte Smith, although local residents continue to call it by its earlier name, St. Stephens.

Such an extraordinary gift from the god of the sun, one given, could not be ignored. In the minds of the people who inhabited the island at this early juncture, a constant reaffirmation of their appreciation for Helios' generosity would have required regular offerings of thanks-- lest the precious gift be taken away. Later inhabitants of Rhodes had the reputation for knowing how to keep well their festivals-- especially the Halieia, which honored Helios. Once this special place was discovered where Helios choose to reveal himself as fully as he ever would to humankind, it would have immediately become the center for sun worship at Rhodes, a venerated place where the cult to the island's patron deity was certainly first established. The location of this most sacred place atop Monte Smith leads to the second of our previously mentioned considerations.

Humans have always been attracted to high places, especially the highest in a particular region. Early peoples assigned sacred meaning to such heights, and mountain worship became a widely practiced religious phenomenon in numerous societies-- including Mt. Olympus for the Greeks; Mt. Sinai for the Hebrews; the Japanese veneration of Mt. Fuji; and the humbler but not unimpressive local heights that attracted a great many Native Americans. At Rhodes, there also was a definitive high place-- one that would elevate the worship of the sun there above all other places in the Greek world, and, ultimately, make the choice a simple one about where to locate the Colossus of Rhodes. It is known today as Monte Smith, a high promontory extending outward into the sea, whose base, some 300 feet below, is now skirted by two separate busy thoroughfares moving in and out of modern Rhodes City. ${ }^{8}$ It is from the top of this distinctive promontory that one can observe the

8. See note 9 and Figure N.2, infra. 
uninterrupted arc of the sun, as Helios daily makes his way from sunrise to sunset.

Monte Smith takes its more recent name from the British admiral who had thought the site so strategically significant that he once had a villa and observation post there during the Napoleonic Wars. (Likewise, the Italians occupying the island during World War II, placed a large gun emplacement there for the same reason.) That the advantages of the location have been recognized since early times is confirmed by the fact that it was on Monte Smith where the ancient citizens of Rhodes choose to establish their acropolis (remains of which can still be seen) and placed on its apex the great temple of their city's guardians, Athena and Zeus. It was nearby the precinct of this same temple where the Colossus of Rhodes was most likely located when built in the early third century B.C.

The ancient people of Rhodes choose the heights of Monte Smith to place their most sacred sanctuaries (probably at least since Minoan days) for a reason, and it appears that reason was that they considered those heights to be the most hallowed in their local geographical setting-- and where they could best honor Athena and Zeus. That they would subsequently choose the same sacred site as the most appropriate place for the Colossus of Rhodes, patron deity of their entire island, seems just as predictable. From this height, both the rising and the setting of the sun could be observed without moving a step. This rare phenomenon would have been indelibly "catalogued" from the time that the earliest observers on Rhodes noticed it, simply because in their concept of the universe, the sun was the single most conspicuous feature in the world.

As centuries passed and more knowledge about the universe and how it worked was gained, old religious traditions about the sun and its powers never lost their popular grasp - so much so that even in wider Greek society, the assertion by the philosopher, Anaxagoras, that the sun was only a burning chunk of metal helped get him banished from Athens in the mid-fifth century. For the ancient Rhodians, the underlying importance of their veneration of the sun was shared almost universally. On their island, it was the defining uniqueness of what happened at the apex of Monte Smith which made it the recognized place where the people would erect the Colossus, the greatest monument ever dedicated to Helios, patron of their island. It was their most sacred location, where each full day of sunlight mirrored Helios' own bronze glory as the Colossus of Rhodes. In more earthly terms, it was also the least controversial and most diplomatically neutral choice for an island inherently torn by divisive politics to locate a dedication to be embraced by all.

Monte Smith would have been the location for the Colossus for an elemental reason, as well. It concerns the ground on which the Colossus, whose size and weight would challenge even the most advanced engineering and technological skills of the day, could be erected without fear of the earth beneath it giving way and causing the giant statue's collapse. No skilled craftsmen can foresee every contingency that might affect the integrity of their work, but they can take measures to safeguard it against what they do know. Earthquakes are a fact of life even today at Rhodes, and, considering their 
frequency, there could easily have been a number of them the Colossus survived before the catastrophic one that felled it around 226 B.C. The Colossus never would have been built if it were thought, at the time, it would collapse within the century of its construction. The solid native rock, limestone in this case, atop Monte Smith, would have contributed to that confidence of safety.

Such a natural foundation at the zenith of Monte Smith would not only have best solved the problem of ensuring the statue's stability, but it also would have eliminated the need to prepare much, if any, additional reinforcement at ground level to support the Colossus' weight. The plateau's heavy rock top provided all that was needed. That is significant because whenever a relic resembling a platform made for a large statue is discovered today at Rhodes, a swirl of controversy begins as to whether it could belong to the Colossus. Rhodes was full of "colossal" sculptures, some apparently quite big. One was Lysippus' mighty portrayal of Helios in his chariot, still standing when Cassius the conspirator was dissuaded from carting it off in the 40s B.C. ${ }^{9}$

Consequently, there probably is never going to be such a definitive discovery because no groundwork of any consequence ever existed for the

9. This earlier colossal sculpture by Lysippus, which, unlike the Colossus of Rhodes, apparently survived intact to the time of Cassius and beyond, is probably the more appropriate candidate (if there is one at all) for Ursula Vedder's proposal as to where the Colossus was once located-- a site on the side of the acropolis, below its peak and highlighted through satellite imagery in Figure 2.8 of her recently published summary, "Was the Colossus of Rhodes Cast in Courses or in Large Sections?" in Artistry in Bronze: The Greeks and Their Legacy. XIX ${ }^{\text {th }}$ International Congress on Ancient Bronzes, held at the Getty Center and Villa, October, 2015 (consulted at www.getty.edu/publications/artistryinbronze/large-scalebronzes/2-vedder/). This and her other publications on the subject (listed in the above reference), wish to place the Colossus in what was previously identified as the Sanctuary of Apollon Pythios, which she now identifies, correctly, I believe, as the Sanctuary of Helios. There is certainly more compelling reason to assign the entire area, including the large Doric temple, to Helios, the patron god of the Rhodians, rather than to Apollo (see, also, Schipporeit's [supra, note 2] observations). Vedder's enticing conclusions about a large statue standing on what she identifies as "the remains of [a\} base" to the northeast of the temple are partly the result of what she concludes is a favorable comparison to the dimensions for the 58' $x 48^{\prime}$ x 7' (2.2 meter) base of Nero's later colossus at Rome-- also about the same height as the Colossus (e.g. Pliny, Natural History 34.18.45). However, such a "base" would conform just as well-- or better-- to the requirements needed for Lysippus' older and "most famous" (Pliny, 34.19.63) representation of Helios in his Chariot. Lysippus' Helios would, unlike the fallen Colossus, continue to need its base since it was still in place during Cassius' time, some two centuries later. Also, it still cannot be demonstrated that the remains were not something other than a base for a large statue. Typically speaking, such a large platform of stone would more likely be recycled and used elsewhere. Also, its location would have prevented a complete view of the Colossus because the surrounding environment would have obscured the ability to see it in the round. The area is also not open enough to accommodate twelve years of construction disruption, workshops, and the probable hundreds of laborers who would have been housed and actively involved during the building of the Colossus. Lastly, if, as suggested here, in Kebric (2019b) (and elsewhere), the Colossus also served as a "lighthouse," its beacon would be obscured by such a location, placing it too far down the acropolis hill to be an effective signal in all directions to guide ships into Rhodes' five harbors at night. For these and other reasons enumerated in this study, we would still maintain that the Colossus was placed higher up on the acropolis-- at the very top of the heights of Monte Smith. 
Colossus. The Egyptians had been leveling off native limestone foundations for pyramids and huge statues for more than two thousand years. Considering the influence of Ptolemy I on Rhodes at the time of the Colossus, there can be little doubt that the best Egyptian engineers involved with building the new Ptolemaic capital at Alexandria, would also have been consulted about the most suitable natural foundation on which to set the Colossus. There was no more obvious place than atop Monte Smith, already supporting the tremendous weight of the large buildings there.

Such an optimal location would also eliminate any ideas about a more tenuous placement of the Colossus on the edge of one of Rhodes' harbors, whose shores, no matter how much they might be reinforced or enlarged, simply could not provide an equally firm base (or protection) for the giant statue-- especially during extreme weather. Discovering an appropriate location for the Colossus within the city, already filled with temples, public buildings and offices, businesses, and residences, which, by the end of the fourth century B.C., would have occupied the most favorable and strategic locations, would have been just as difficult. This problem would have been compounded by the fact that there had been tremendous damage to the city walls and much of the urban center from Demetrius Poliorcetes' recent siege of the city in 305/4 B.C. His giant engines rose high above the town's defenses and continually peppered it with large round stones like the ones now displayed in the archaeological rooms at the Grand Masters Palace. One wonders what damage the heavy projectiles, most larger than basketballs, would have caused when they struck statues, colossal or small, that had not been secured or protected. There would have been no way to protect the Colossus from complete destruction in a "downtown" location in a subsequent attack.

It goes without saying that protecting the soon-to-be built Colossus from such damage would have been foremost on the minds of Chares of Lindos, the statue's builder, and the Rhodian Republic's leaders when they determined the safest location for their huge project. The Colossus was also to be regarded as a votive offering to Helios for his help in fending off Demetrius. Demetrius was, as Plutarch emphasizes in his negative biography of the warlord, the kind of person who would not let religious or any other scruples prevent him from laying waste to such a statue. Should he decide to return, despite any terms he had earlier negotiated with the Rhodians, he would have viewed destroying the giant target as the best way to demoralize them and hasten their surrender. With the earlier siege still in mind and no guarantee that any one of Alexander's Successors might find it advantageous to attack Rhodes in the near future, a colossal statue of Helios in an open plaza or large garden in town would be vulnerable to the same missiles that had already pounded much of the city into rubble. The destruction of a votive offering of Helios built specifically to vouchsafe his protection of the island would be a sad (and ironic) statement, indeed, for the Rhodians.

Just clearing away the debris from Demetrius' siege, rebuilding important structures, and, at the same time finding a sizable piece of cleared land in the urban center big enough and firm enough on which to erect a statue the size 
and importance as the Colossus would be an almost impossible task. It could not be placed just anywhere. Presuming one has a choice, nobody would embark on a project so huge and expensive without first examining the ground on which it would stand. In a future century, architects at Rome were directed to build the Colosseum on land where Nero's Golden Palace had once stood. Even though they already knew it was not entirely capable of supporting such a huge structure, they had no alternative but to proceed, knowing they were taking a huge risk. Fortunately for them, it took another 1,300 years before the price for their gamble was paid. Modern experts cite that the main reason why the Colosseum's outer south wall finally did collapse during an earthquake, as did the Colossus, was the less stable alluvial terrain on which that side of the arena had to be built.

There is a perennial wisdom architects and engineers pass on to one another about their craft-- and similar preliminary investigations of construction sites had become routine long before Chares began building the Colossus. As mentioned earlier, he would have had the benefit of more experienced Egyptian architects and engineers from Alexandria, who had a combined experience of over 2,000 years in determining the most suitable ground on which to build massive structures and colossal statues. Suggesting that Chares would have proceeded otherwise is not realistic. By the time he started the Colossus, he would have known that the formidable limestone shelf atop Monte Smith, visible to all as it protruded out into the sea some 300 feet below, provided what was necessary to support the Colossus. It was already home to the great Temple of Athena and Zeus and other structures (including the still visible subterranean passages of the Nymphaeums). The ground was level and spacious enough so that it did not need much, if any, additional preparation. The heights of Monte Smith would also protect the Colossus from damage in any future military attack.

Consequently, Monte Smith provided the ancient Rhodians with all of the requirements necessary to build their colossal statue. It was 1) the highest and most protected natural elevation above Rhodes' major city and capital, and had previously been recognized as the most sacred spot in the area by the placement of the great Temple of Athena and Zeus there; 2) a unique location where the daily movement of the sun god, Helios, patron deity of Rhodes, could be observed in its entirety from sunrise to sunset; and 3), was a thick limestone plateau, whose solid foundation offered the island's best and most convenient topography on which to construct the Greek world's most monumental offering to Helios. By themselves, each of these three extraordinary factors might be offered as the major reason for why the Rhodians would decide to build the Colossus of Rhodes where they did; together, they are a remarkable triad of physical realities centered only at this one place on the island.

Today, as the photos included here show, the singularity of Monte Smith continues to be recognized by modern technology. Its solid apex is now home to a variety of telecommunication towers. Erected within the past two decades, they are both an archaeologist's and environmentalist's nightmare, even rising 
up amid the remaining stones of the Temple of Athena and Zeus at the very top of what once was the ancient acropolis of Rhodes. Nonetheless, their purposeful placement further supports the Colossus' location there since these towers were erected above the city on the apex of Monte Smith so that they could receive and send the clearest and strongest signals. The "needs" of the ancient Rhodians were different, but the apex of Monte Smith was just as important to them for reasons that wholly escape the commercial interests of today. The best location at Rhodes for the clearest reception of signals from the heavens has not changed - only the gods have. For over 2,000 years, Monte Smith has "answered" the call for both ancient and modern Rhodians.

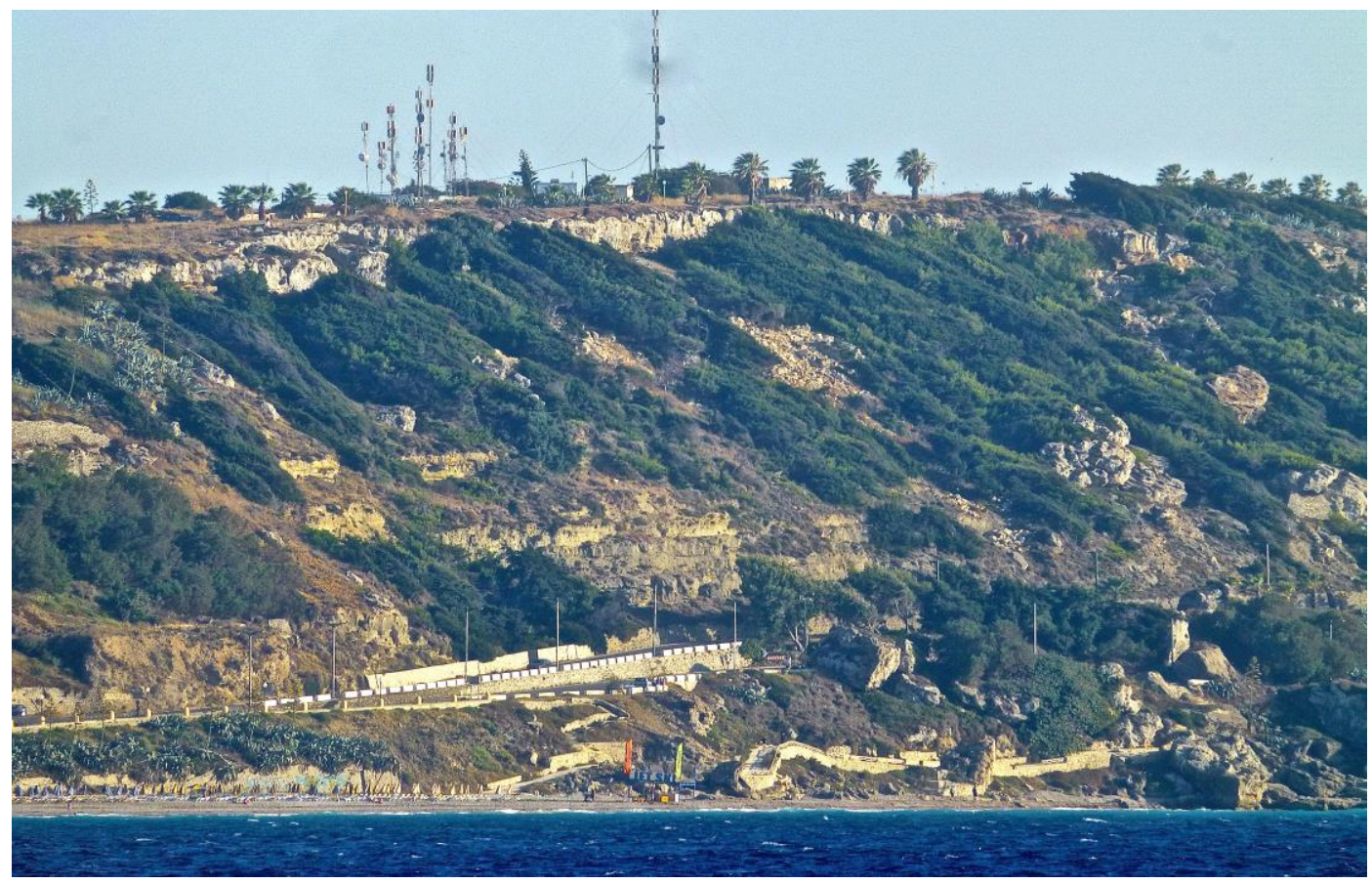

Figure 8. The heavy limestone shelf at the top of Monte Smith is fully visible to ships passing at sea. Such a firm, natural stone plateau would have been an ideal place to support the weighty Colossus of Rhodes, near where the modern $T$.V. and cellular towers are now located on the heights of the promontory-and where the important Temple of Athena and Zeus also once stood, elevated some 300 feet above the sea. The benefits of placing a "lighthouse" here in the form of the Colossus are also clear. 


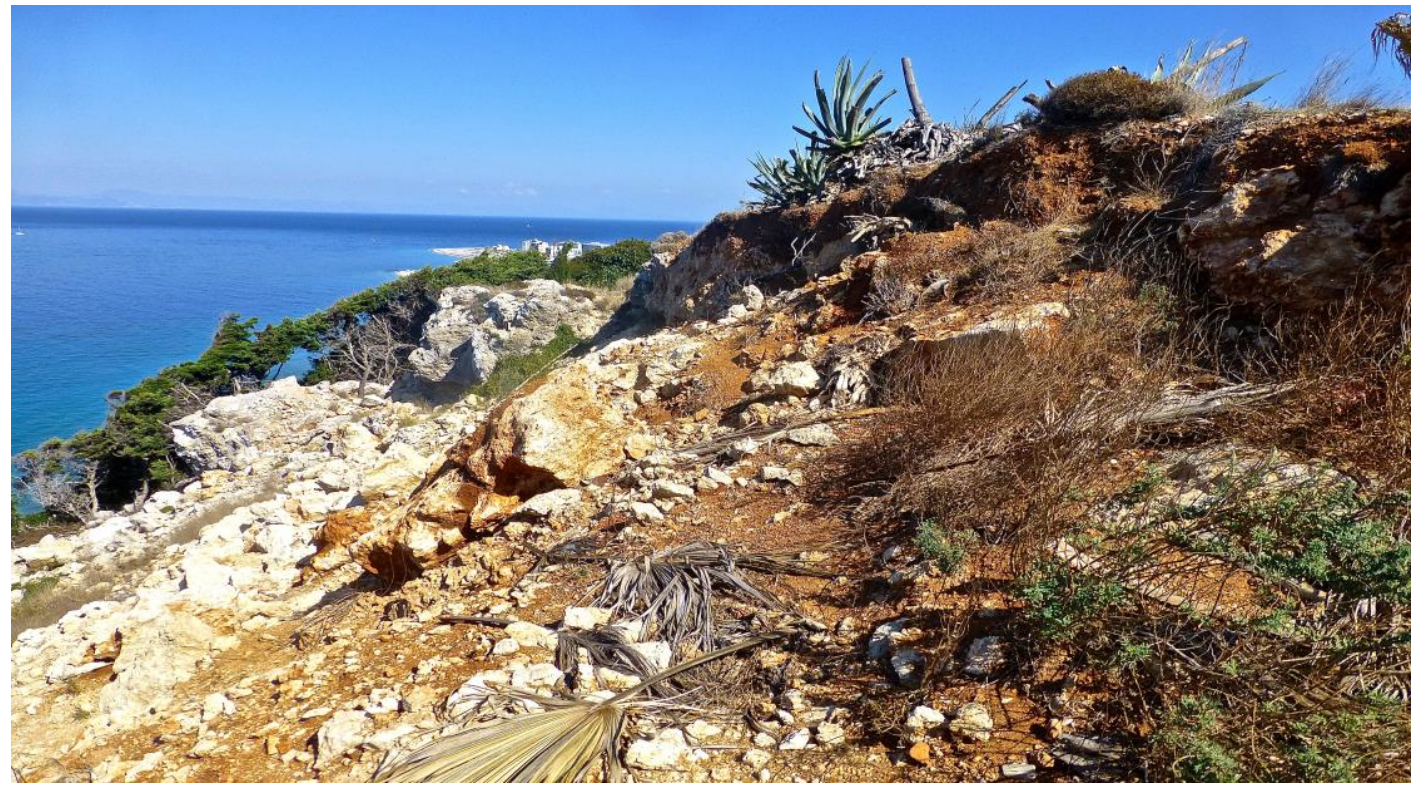

Figure 9. The edge of the stone shelf at the top of Monte Smith shown in Figure 8, indicates its continuing deterioration. Boulders routinely break free and are caught in safety barriers now protecting the highway below. How fast the rate of decomposition has been over the centuries is difficult to calculate, but it seems clear the promontory extended further out when the Colossus was built 2,300 years ago. Consequently, evidence that might have helped determine its location on the summit could have disappeared long ago.

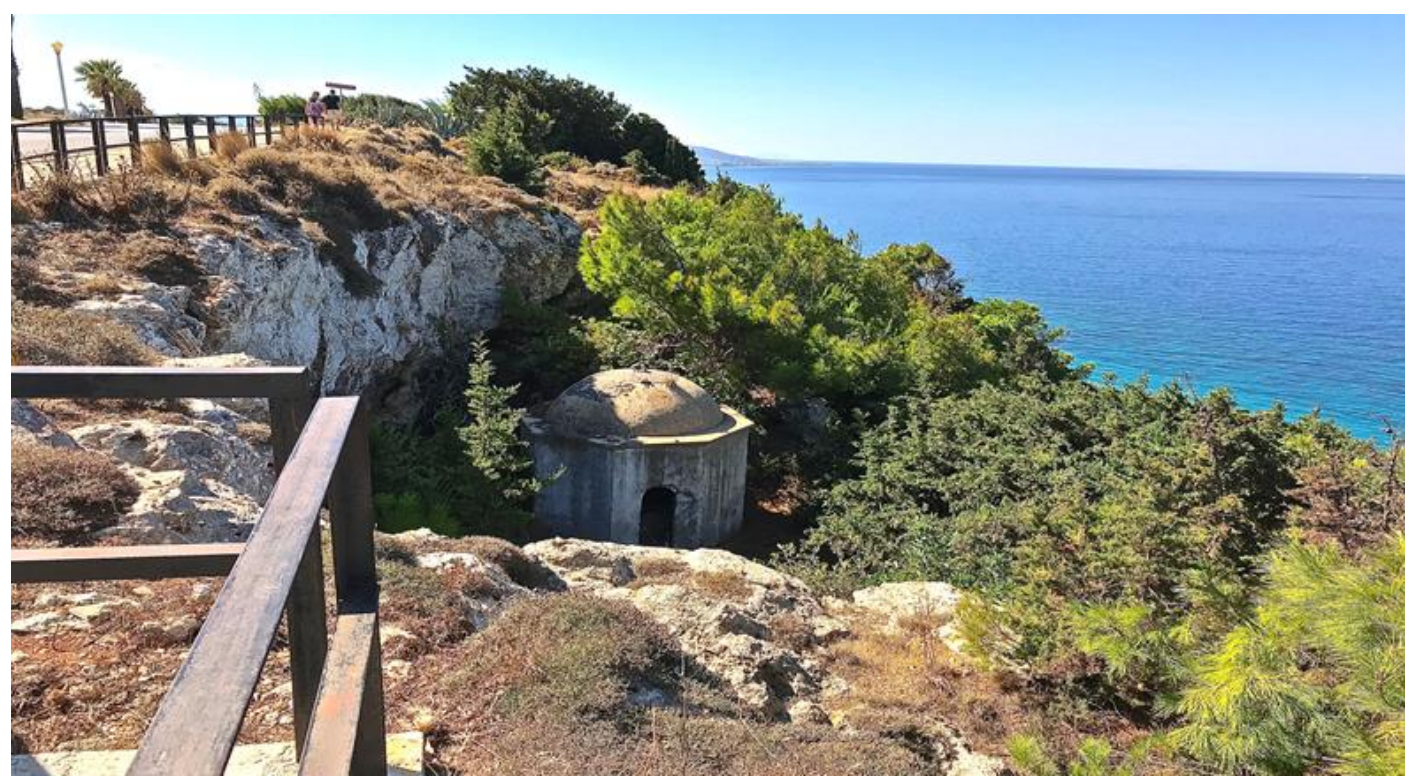

Figure 10. The photo includes the copula of what appears to be a small chapel once used by locals before descending the steep foot-paths that once wound their way down the cliff. The latter are shown in an allied aerial reconnaissance photo of the area from World War II. ${ }^{10}$ The apparent age of the

10. See Figures N.1 and N.2, following the Postscript. 
chapel and the fact that it is still in place (presuming it was not once part of a larger complex) would indicate the shelf's deterioration has been gradual over the last century. However, when the aforementioned 1940s reconnaissance photo is compared with recent Google satellite images of the shelf, there has been noticeable loss of stone over the interceding years. Earthquakes routinely shake the island.

Helios, of course, was not only the sun but also a star. It is only appropriate, then, that his role as such would have continued during the night, as a "star." Pliny had observed about the Pharos Lighthouse (36.18.83), that it "commands" the harbor at Alexandria and at night guides ships into safety-but its uninterrupted light burning brightly could also be mistaken from a distance for a star. The Colossus, too, simply by virtue of its height, guided ships into the harbors at Rhodes, and, built contemporaneously with the Pharos Lighthouse, there is no reason to disbelieve that from the start it, too, was designed with that same use as a light beacon in mind. How else could Rhodes think to become the greatest harbor in that part of the world if ships could not also safely enter its harbors at nighttime or during difficult weather - and the technology for both projects, proceeding at the same time, could be shared through the common interests of Ptolemy I and Rhodes. It is a little-known fact today that even the Statue of Liberty (with which the Colossus is often compared) was originally conceived as a New York lighthouse and may not even have been erected otherwise.

The peak of Monte Smith by itself reached a height of almost 300 feet. With the added 160-foot height of the Colossus, a burning evening "star" of light could have reached as high as the Pharos Lighthouse- or higher. Employing the Colossus as a night beacon could not have been lost on the "city fathers." It also would have provided a utilitarian function for the Colossus that would have silenced at least some high-placed critics of the project as the years passed and the money dwindled. 


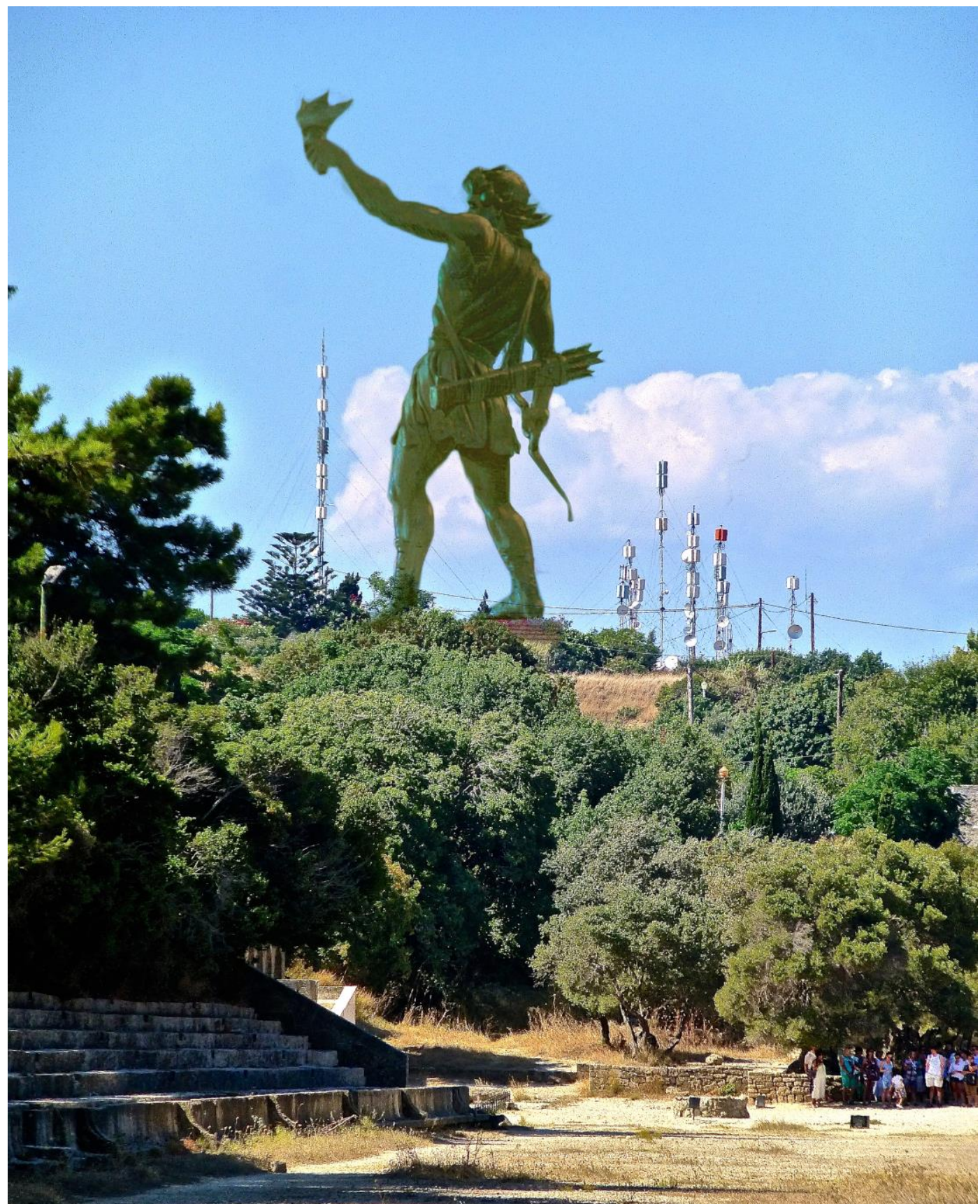

Figure 11. A modern composite photo, showing how a statue the size of the Colossus may have appeared at the top of Monte Smith, as viewed from below about a half mile away at the stadium and theater area of the ancient Rhodian Acropolis. Neither the posture nor appearance of the actual figure can, of course, be known. This image is included simply to convey something of the startling impression the original Colossus could have made. The scale, however, is accurate, judging from the highest of the communication towers (about 75 feet), now situated near where the 160-foot Colossus most likely once stood. Its lighthouse capabilities are obvious. 


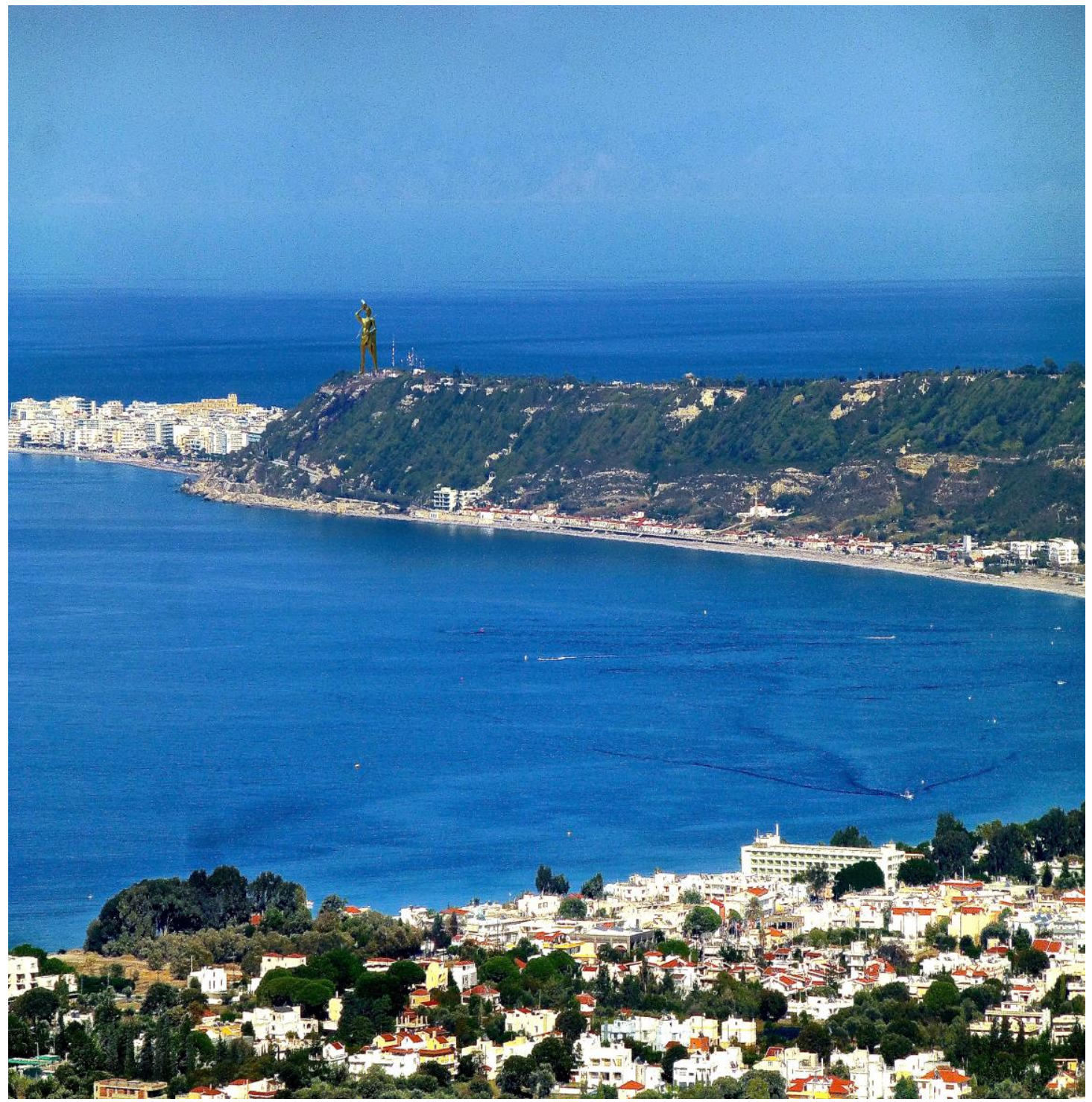

Figure 12. A composite image, showing how a statue the size of the Colossus located atop Monte Smith on Rhodes' ancient acropolis, would have appeared from the elevated heights of Ialysos, one of the three other important centers on Rhodes, where its own Temple of Athena was once located. It clearly demonstrates how the Colossus would have dominated the surrounding area and made a perfect "lighthouse" for harbors all around. The scale of the figure shown is correct, but its stance and appearance are purely conjectural and one of many possible modern Colossus reconstructions. Ixia beach is to the far right in the middle of the photo.

There can be no question that an important light tower had always existed at the top of Monte Smith to guide ship traffic. Because of the Colossus' combined height with the promontory, it would have stood some 460 feet above the sea. A light beacon(s) could have been placed as low as the top of the 50-foot pedestal of the great statue - making it a "star" in every sense both by day and by night. 


\section{East Is East, And West Is West?}

It may be of interest to relate the inadvertent and completely non-academic manner in which the evidence presented here started to accumulate. It began during a pleasant dinner at our hotel on our first night visiting Rhodes on vacation in July of 2015. Before departing for Greece, I had made some offhanded quips to colleagues and friends that while I was at Rhodes, I might as well look around to see if I could determine where the Colossus had once stood. It was not a reason for going to the island with my wife, but, quite unintentionally, my interest began to peak while dining at our hotel.

Perched high above Ixia beach on the northwestern coast of the island almost three miles down from Rhodes City (see Map 1 and Figure12) and bordering on Ialissos (old Ialysos) to the south, we looked straight across the channel to what is today Turkey. It was dusk, and we periodically glanced up from our meal as a steady stream of aircraft passed by, descending with the sun while heading to Diagoras airport, some six miles further down the coast and where we had arrived earlier. As we continued to watch what was becoming a beautiful sunset, something unconsciously began to draw our attention-something that was not quite right. In fact, it was extraordinary. The sun was not setting in the west as it was supposed to do away from Turkey, but it appeared to be going down into the mountains over Turkey - a seemingly geographic impossibility since Turkey is situated east of Rhodes.

At first, we paid no attention to what was happening since our main interest was enjoying our food, but as the sun continued to lower on the horizon, it became increasingly clear that it was moving "erroneously" toward the Turkish coastline-- where it eventually disappeared behind the mountains in what was once ancient Caria. "Isn't the sun supposed to be setting in the west?" we asked the waitress who was serving us. She immediately got a puzzled look on her face, understanding what we had asked but not really comprehending the reason. "The sun," we said again, pointing in the direction of where it had gone down. "It's supposed to set in the west, but that's Turkey over there, and the sun just set in Turkey. Turkey is east of Rhodes." She paused for a moment. "You know," she said, "I've been working here all summer, and I've never noticed that." She continued, "I'll look at a map when I get home-- but let me ask the manager. Maybe he'll know...."

Inevitably, it always seems to be the case that the people who live in a place know less about it than someone who visits, usually because they become so used to the environment that they no longer notice its particular characteristics. The unusual behavior of the sun had not attracted any notice by the manager either, even though he was there almost every night during the summer at sunset. "The sun," we repeated to him. "It appears to be setting in the east even though that's physically impossible. It must be the particular geographical location of Rhodes to the Turkish coast that makes it appear from here that the sun is setting in the wrong place." He realized what we were saying immediately, although it was clear that he really had not previously thought much about it. Now, however, he added something to the conversation 
just as unexpected. "Do you see that hill over there up the coast that's a little higher and stands out from the others above the water?" he pointed in the opposite direction toward Rhodes City to the promontory known today as Monte Smith. "It's just above the old city acropolis, and if you stand at the very top, you can see the sun come up in the morning and watch it all day long until it sets in the evening.... Sunrise to sunset from the same place." Without even knowing it, he had revealed what was probably the best location for where the ancient Colossus of Rhodes had once stood-- although he did offer his suspicions that a smaller version of a statue of Helios had probably once stood there.

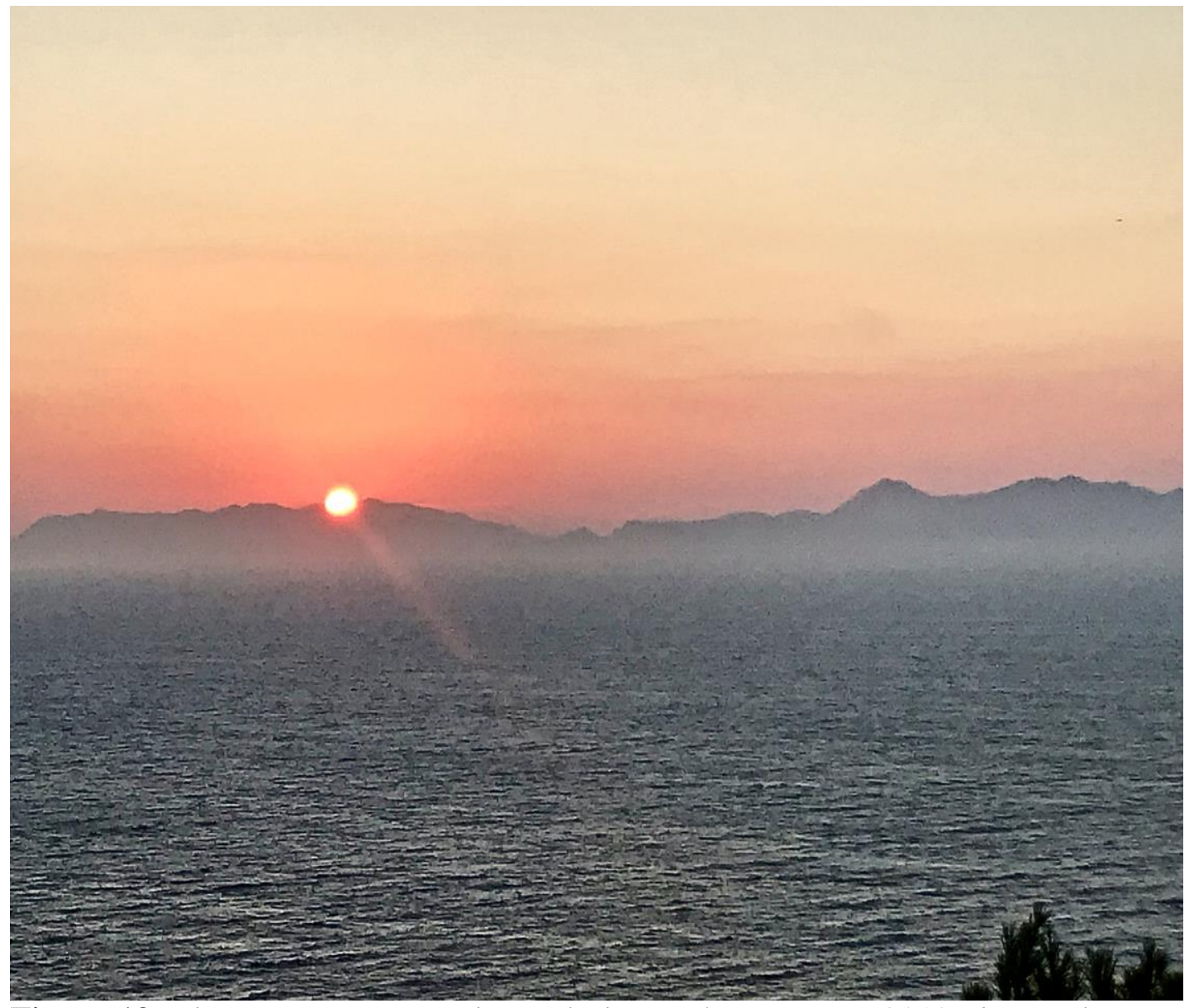

Figure 13. The sun setting over the Turkish coastline in June, 2018, during the Summer Solstice. Viewed from the summit of Monte Smith on Rhodes, as it is here, the sun appears to be setting in the east, directly over Turkey, or what was once ancient Caria. In antiquity, the Solstice would have been marked well on the island, and this peculiar event noted and celebrated as Helios' special behavior at Rhodes. The center of that celebration had to have been atop modern Monte Smith. On Rhodes, the Astronomy Café at Faliraki has an annual Summer Solstice party.

Source: Photo by Ildiko Mikos, MD. 
During the course of dinner, my previously casual attitude about possibly discovering the location of the Colossus changed dramatically. I had always thought that the major reason for why Rhodes was called the "Island of the Sun" was that it was, and still is, so hot there- and, during the summer, it is indeed hot. The city of Lindos and its famous ancient acropolis, a little over half way down the opposite (eastern) coast of Rhodes, is even pronounced in some tourist guides the hottest place in all of Greece. It is hot, but it does not seem any hotter than the Acropolis in Athens on a sun-drenched day during the summer; but we now saw that the glaring sun and heat may not have been the only reason the Greeks had chosen this particular island as the home of Helios. We had just become party to two of the momentous kinds of realizations mentioned earlier that inevitably attract the attention of ancient peoples and lead them to consider such out-of-the ordinary phenomena as divine or sacred - so much so that the indelible impressions left by them can affect a society for millennia. Such stories always arise early in once illiterate societies from a common pool of folk tale, fiction, and saga to explain obscure beginnings for things or happenings that are otherwise unknown. Here were two examples of such phenomena, otherwise inexplicable to ancients, with which we were now serendipitously confronted on Rhodes. In this instance, they are naturally occurring oddities quite apart from the usual unfolding of what everyone in a particular geographical setting is used to seeing on a dayto-day basis.

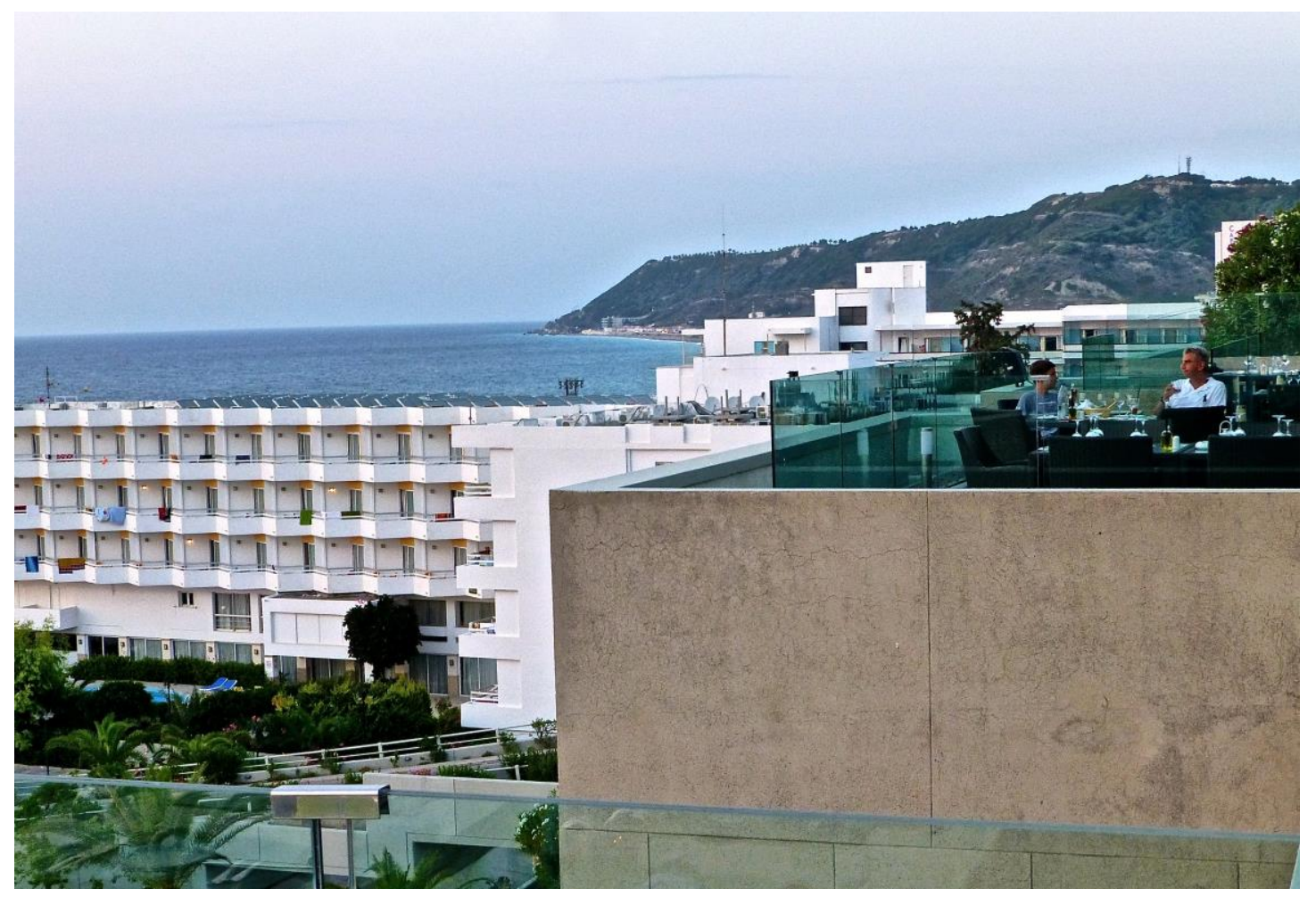

Figure 14. The promontory of Monte Smith, projecting out into the sea between Ixia beach (and Ialissos) to its south from our hotel, and Rhodes City to the north. Near the tall antenna (faintly visible in the distance in the middle 
of the photo) at the promontory's apex is the most probable location for the Colossus of Rhodes-- and from where, as our Maître D' first made us aware, one may view the unique local experience of tracking the complete arc of the sun from sunrise to sunset.

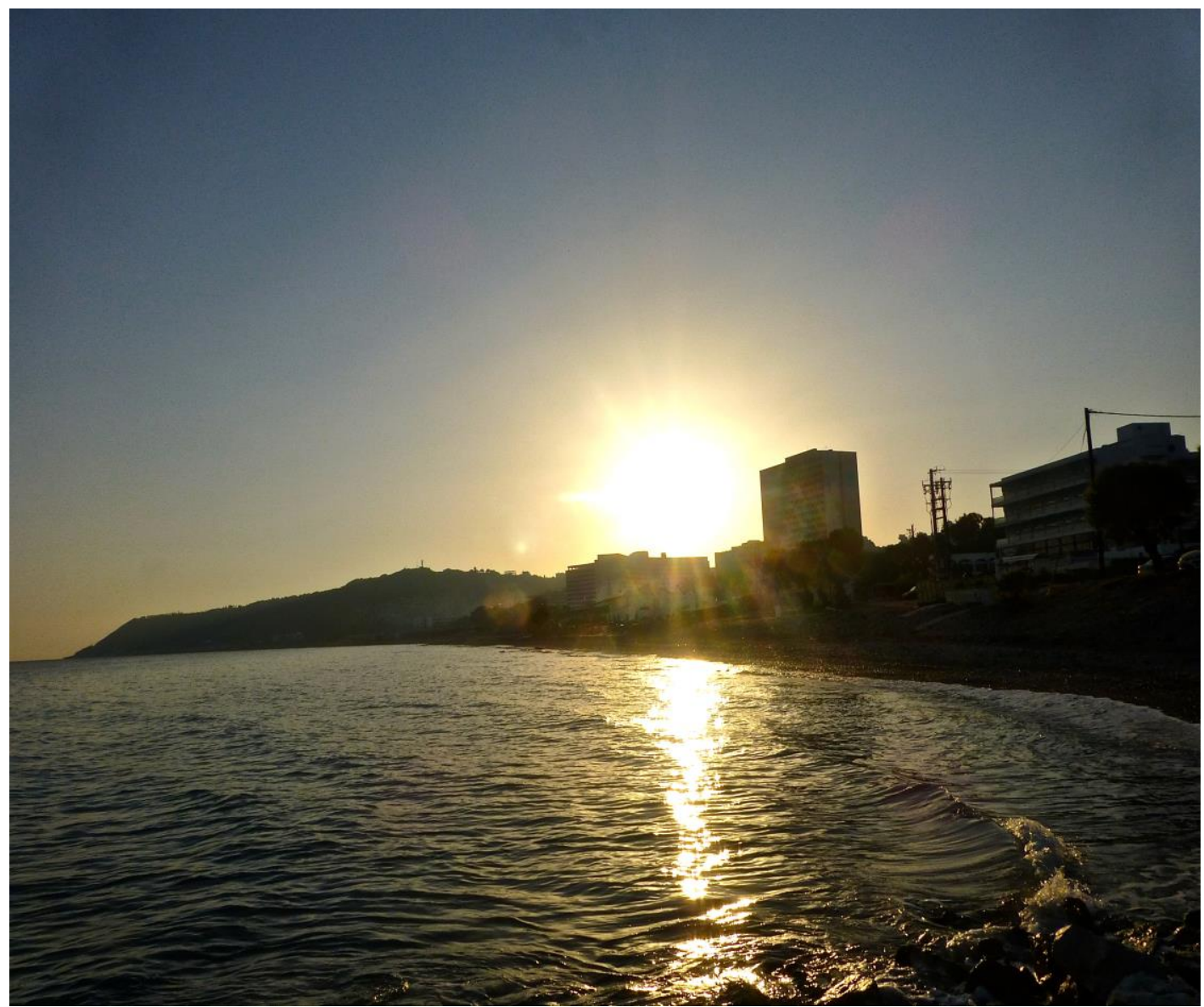

Figure 15. A July sunrise from Ixia beach, south of Monte Smith to the far left, from the top of which the sun can be seen rising up from the sea and continue to arc across the sky until setting in the hills of the Turkish coast, as in photo 13. From this perspective, the sun even appears to be rising more to the north over Rhodes City on the other side of the promontory than the east-another apparent anomaly because of the island's unusual geographical situation.

Our Rhodian friend at the restaurant shared what was common knowledge only among residents of the area: It was on Monte Smith, and exclusively on Monte Smith, where one could stand and observe without obstruction a full day of the sun's movement - the complete arc of the fiery ball of Helios, which would have been especially pertinent at the Summer Solstice that had occurred only three weeks before our visit. This could not possibly have gone unnoticed by early residents of Rhodes, especially the priests, and, considering how obsessed other societies were in calculating the Solstice, there can be no doubt that the apex of Monte Smith would have been attributed the most sacred meaning from earliest times on Rhodes-- especially at this precise time of year. 
Today, we might not be seeing the sun's daily movement from atop Monte Smith exactly as our Rhodian counterparts did over 2,000 years ago-- but it cannot be too much different from what they had observed.

On early Rhodes, the unusual, if not unique, opportunity in the experience of its ancient inhabitants to stand atop Monte Smith and watch the most dominating feature in their environment go from sunrise to sunset without obstruction was privilege enough. To watch that same sun set over a nearby land mass that, for all appearances to a society that was not always geographically astute, was in the east instead of the west, was another of two distinct oddities of nature that would definitely have challenged their beliefs and attitudes - especially at the Summer Solstice.

There may actually be indication of an observation of the sun's apparently erratic behavior of setting in the east instead of the west imbedded in the stories from early Greece-- specifically through the tradition that Zeus had "reversed the laws of nature" to deceive Thyestes into abdicating the throne of Mycenae. Favoring Atreus, Zeus had him trick his brother into promising to abdicate if the sun reversed its course midway in the sky and turned around to set in the east where it had arisen. Since this had never happened before and was regarded as impossible, Thyestes confidently agreed to the proposal, and, once done, Zeus had Helios turn around his chariot and head back toward the dawn. Thyestes lost his ill-gotten throne-- and never again did the sun set in the east. This was, to say the least, regarded as a unique and momentous occurrence to all confronted by the story: The sun was one of the few things that was constant and provided confidence in a world in which few things were guaranteed. The story emphasizes the belief that it was utterly impossible for such a thing to happen - and since it necessarily involved Helios, the patron god of Rhodes, the story of Thyestes and Atreus may have originally sprung from the strange phenomenon noticed early on at Rhodes and detailed here. Stranger things (at least the appearance of such) seldom occur, and this story originated in an illiterate world where explanations were rarely manifest. ${ }^{11}$

This once extraordinary "tradition" involving the sun continues today in secular form in the observation made about Monte Smith by our Maître D' at the hotel. For him, his remarks were special only in the sense that he was passing on a tidbit of local knowledge that our questions had caused him to remember. It had no significance other than he thought it would be of interest to us. The unexpected natural occurrences about which we had just learned cannot have many parallels, if any, on Rhodes - or anywhere else, for that matter. What he said about Monte Smith appears to be quite unique-- which is most important for our interests about the Colossus of Rhodes. To be able to observe uninterrupted the most influential heavenly body travel from one side of the sky to the other without ever moving a step, while also watching it act in what seemed to be completely unnatural behavior by setting in the east rather than the west, was something that early observers would have had great

11. See, Robert Graves, The Greek Myths: 2, 111c (with ancient references in his note 6) (Baltimore: Penguin Books, 1966 edition). 
difficulty comprehending. They may not have known much about geography outside their local region, but they did know, especially sailors, where the sun was supposed to rise and where it was supposed to set. The pattern was inexorable - and only Helios, himself, could change his own behavior. On Rhodes, he chose to end his day not in the west, as he did everywhere else-- but in the east. Nothing could have confounded primitive observers more or made a greater impression about the uniqueness of Rhodes-- and there may have once been other visible signs. Animals and humans have from the beginning naturally followed the path of the sun for warmth and directional purposes, and at Rhodes, the sun's unusual movement may have affected "traffic patterns" in a way different from those elsewhere. If so, that, too, would have been noticed- by "outsiders," in particular. It appeared that Helios did whatever he pleased at Rhodes: It must be his home because there was no other explanation.

In antiquity, there always had to have been a sacred shrine of some sort to the sun god atop Monte Smith, where this extraordinary contradiction of nature took place and could best be observed. The city's lighthouse, or "fire" tower, that used Helios' nighttime flame to direct ships into harbor, was also doubtlessly there. As Greek society began to mature and further develop its religious behavior, this "personal" association of Helios with Rhodes never ended. At some point along the way, it became known, along with the intense heat, as the Island of Helios. 


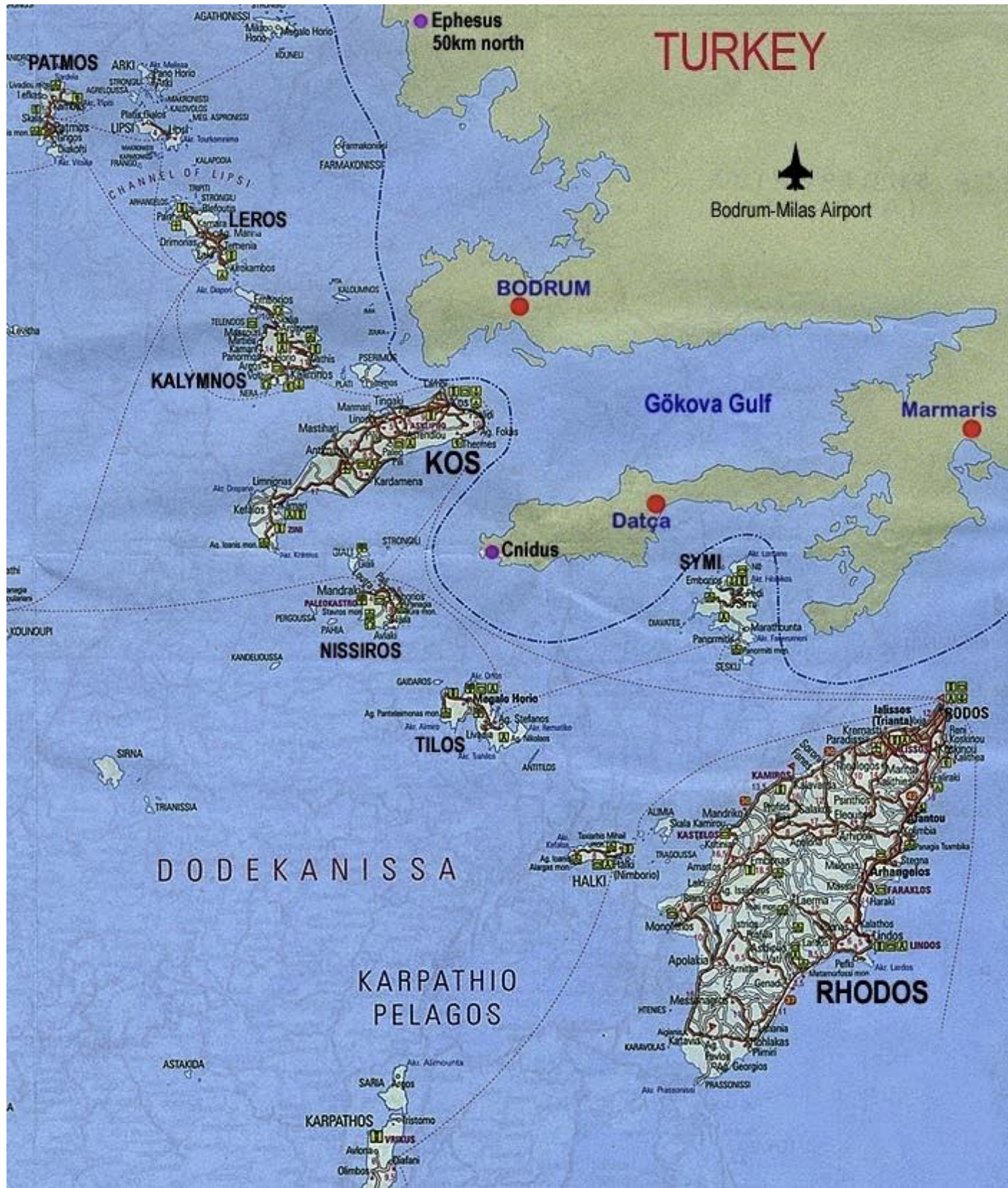

Map 2. This map shows that Rhodes' orientation is more NE by SW than N-S. Its unique position below the Turkish mainland (Figure 13) can produce the effect that the sun is setting in the east over Symi and Turkey, which are actually to the NW of the western coast of the island. It may have confused early observers on Rhodes and sailors navigating the local waters, thinking that Helios was doing something unique here- a reason to conclude Rhodes was his island. Red lines for ship traffic today demonstrate the approaches to the island mostly pass by Monte Smith, the most compelling location for the Colossus. For many reasons, shipping lanes do not change over the centuries-and probably have not here. 


\section{A Second "Colossus" On Monte Smith}

Every divine, practical, and visual requirement for placing a colossal statue dedicated to the god of the sun was fulfilled at the summit of Monte Smith. In addition, Polybius recounts (31.4.4) that a second colossus, this one dedicated to "the Roman People" and nearly 45 feet tall, was erected in the temenos of the Temple of Athena on the same mountain top, in $164 / 3$ B.C. ${ }^{12}$ It is too coincidental that this later colossus, even though a diminutive one and dedicated to Rome, were not also meant in some way to call to mind the much grander Colossus of Rhodes that once stood there-- and whose remains still laid close by. Rhodes had placed itself in a very difficult position in the new Roman order, and the location selected to erect this second colossus was the most honored they could offer in their effort to placate Rome.

Rhodes had put itself in a potentially fatal position after interfering in Rome's war with the Macedonian king, Perseus - injudiciously offering to arbitrate a settlement with the king. Rome did not forgive such a trespass, and when the war, lasting from 171-167 B.C., ended with Perseus' crushing defeat, Rhodes had great difficulty justifying its behavior. According to Livy (e.g. 45.10.1-15; 20.4ff.), the Rhodian explanation found little sympathy at Rome, which now regarded the island republic as neither ally nor enemy- but as a troublesome meddler that had been playing both sides for its own benefit. War was even discussed, but, fortunately for Rhodes, the proposal was dropped. Nonetheless, the Rhodian hierarchy quickly learned that in their rapidly changing world, Rome's displeasure was something to be avoided at all costs.

12. Polybius' narrative is incomplete at this point, and the statement that the Rhodians erected this new colossus "in" the Temple of Athena is certainly more the result of the later condensation of the text than reality. There is no possibility that a 45 -foot statue could be placed inside the temple, itself. Even the gold and ivory statue of Zeus, another of the Seven Wonders, was not that tall, and Strabo, one of our sources for the Colossus, also, noted that the seated Zeus looked cramped within his much larger temple-- as if his head would have gone through the roof had he stood up. The only realistic location for the Roman "colossus" would have been in the temple's sacred precinct, or temenos, atop the Monte Smith acropolis. Like the original Colossus, no trace of this later and much smaller colossus remains. As for the identification of the temple, there can be no doubt that Polybius was referring to the Temple of Athena atop Monte Smith. The fact that the remaining summary only identifies the location as being on Rhodes would imply that his readers would have automatically known which of Athena's four temples on the island was meant (if they even knew Rhodes had four such temples). Under the circumstances, the one the Rhodians offered Rome as home to the new colossus could only have been the largest and most prominent one, foremost in the Roman's mind, atop the acropolis of their capital. Considering the dire circumstances from which the proposal for the new colossus arose (see discussion in the text above), it would have been an insult for the Rhodians to offer any location other than at the zenith of their most sacred mount. Frank W. Walbank, A Historical Commentary on Polybius, Volume III (Oxford: Oxford University Press, 1967; Special Edition for Sandpiper Books, Ltd., 1999), 470, agrees. The same conclusion is followed by the Rhodian archaeological authorities who organized the permanent exhibition, "The city of Rhodes from its foundation (408/7 B.C.) to the Roman period," displayed on the north side of the bottom floor of The Palace of the Grand Master. Walbank further suggests, most probably correctly, that this new colossus would become the center for the cult of Rome on Rhodes and its accompanying festival. 
With their offer to build a new colossus and place it atop their most sacred mount with the temple of Athena and Zeus and the ruins of their once renowned Colossus, they were making a gesture of supplication probably unprecedented in their history.

At the conclusion of the Third Macedonian War in 167 B.C., "Rome stood forth as the ruler of the world, tolerating neither opposition nor indeed anything but unquestioning compliance with her wishes." 13 Anti-Roman parties existed everywhere, including at Rhodes-- but how, if, or when, they would suffer remained unclear. Foremost among those already punished was Macedonia, where the Antigonid house was extinguished, and King Perseus, once on good terms with Rhodes, was dragged off to die in a Roman prison-- the victors taking what they wanted from the once proud monarch, including the royal library. In retribution for Epirus' support of Perseus, even though feeble, Rome destroyed seventy cities and 150,000 Epirotes were dragged off into slavery. Roman memory was a long one and Pyrrhus' invasion a hundred years earlier also had not been forgotten- or forgiven. As for Greece's pesky Achaean League, it was gutted, and 1,000 of its elites (including Polybius) were led off to internment at Rome. Few ever returned. In dealing with Antiochus IV, the Seleucid monarch whose underestimation of Roman power lead him to assume control of Egypt, Rome quickly showed him the "error" of his ways. The Senate's envoy, Popilius, arrived at the Egyptian shore with a small contingent, and, as the story goes, drew a circle around Antiochus in the sand, ordering that before stepping out of it, he "agree" to remove himself and his forces from the country. Antiochus wisely acquiesced. Seldom has there been a more pointed demonstration of outright power.

Dispassionate observers of growing Roman strength must also have once viewed the political maneuverings of Rhodes and Eumenes II of Pergamum during the unsettled period before Rome dominated, as something like "tagteam" opportunists-- each scurrying off to the capital to report any real or imagined rival's threat to undo Rome that could benefit either's ambitions. At the time, it was useful for Rome to reward such "service," but there was no longer reason to keep the good will of former "allies." Eumenes was informed that his suspected collusion with Perseus made any future visit to Rome unwelcome, and the king, fully understanding the message, meekly settled down into Roman servitude.

As for Rhodes, whose wartime relationship with Perseus was also viewed as much too cozy, Rome was content in 167 B.C. to humble the island economically. Delos, another popular Aegean port of call, was declared a free port (e.g. Polybius 30.31.10-12), thereby encouraging merchants who feared displeasing Rome to do business there. By this measure, "the greatest calamity inflicted on our town...," Rhodian prosperity declined precipitously.

Such blatant aggression within so short a period against such formerly significant individuals and nations pointedly delivered home Rome's intended

13. Ernst Badian, Foreign Clientelae (264-70 B.C.) (Oxford: Oxford University Press, reprint, 1972), 96. 
message. To challenge its power could result in the direst of consequences. For the hapless Rhodians, it was not just a matter of readjusting economic circumstances to get by after the Roman "embargo." knowing what Rome might do that became the most frightening specter of the day. Rhodes may not have even understood exactly what they had done to so alienate Rome, but the world had changed. At Rhodes there was unity in at least one respect: Its usually divisive leadership understood that they had to tread with the utmost caution in dealing with the new super power and do nothing that might upset it further.

By 164 B.C., the political climate had changed for the better, and the Romans, apparently pleased with the contrition shown by their former "adversary," accepted an alliance with Rhodes. Fully comprehending its still precarious position ("begging for [its] own humiliation" and "humbled beyond hope of political revival," in Badian's words ${ }^{15}$ ), the new alliance was tantamount to ending the Rhodian Republic's independence. In such an atmosphere, nothing could have been construed as a grander gesture of (and more fitting tribute to) the full acceptance of Rome's authority than by honoring them with a colossal statue on the same promontory where once had stood one of the Seven Wonders of the World. Having already decided earlier not to rebuild the original statue, the Rhodians could still demonstrate, on a less grand scale, their total understanding of the realities of the world in which they now lived-- by erecting this new 45-foot colossus to the Roman people. They purposely placed it within the complex of their most important temple atop Monte Smith and as close as they could to where the original Colossus had once stood.

The symbolism was clear: The new colossus was as grand a declaration of their subservience to Rome as the Rhodians could offer-- a defining step toward reconciliation with their Mediterranean masters. No guarantee had initially existed that their colossal "gift" would be accepted, but, as they had hoped, Rome found the new statue and its location most agreeable. It was only natural that, once erected, it would also become the focal point for the festivals to the new cult of the Roman people at Rhodes. ${ }^{16}$ Rome approved of the Rhodian offer to raise this second colossus in its name atop Monte Smith and would have regarded any lesser site an insult-- inviting further retribution rather than reconciliation. Perhaps our Maître D' at the hotel restaurant had got it right in respect to a smaller colossus once standing atop Monte Smith.

It is often said that politics are local. The same might be said about religion in earliest times, especially in relation to a heavenly body like the sun. The overall concepts of sun worship might be similar, but there would always be local idiosyncrasies even on an island-- and Rhodes was a very large island. Most people did not stray far from where they were born, and everything they knew, including the peculiarities of their part of the island, came from the few

14. See Richard Berthold's discussion, Rhodes in the Hellenistic Age (Ithaca, New York: Cornell University Press, 2009), 202-212.

15. Badian, supra, note 13, 101.

16. See, Walbank, supra, note 12. 
miles around them and the people they knew and trusted. Few had a complete idea about the entire island. Word would have spread, however, about a center of sun worship at a place like Monte Smith, which would have become known as far back as anyone could remember. It was from its summit that the most important ideas about the sun on Rhodes likely evolved.

From such a vantage point, the sun appeared to set in the east over Turkey. Today, most visitors to Rhodes have enough general knowledge of geography to know that it is only because of the unusual location of Rhodes (Map 2) in relation to Turkey that the sun seems to set in the east over the mountains on the wrong side of the channel. There is no reason to believe, however, that many others over the centuries had not also noticed that something seemed amiss. Very early at Rhodes, an influential individual, perhaps a priest carefully observing the sun, had doubtless beheld what seemed to be a glaring contradiction- especially at the Summer Solstice. Visitors to ancient Rhodes had probably likewise taken note of the sun's curious behavior, and their superstitious dispositions and geographical deficiencies ultimately led to an entirely acceptable, though erroneous, explanation for the sun's apparent setting in the east over Caria (Turkey). As centuries passed, word of this special behavior of Helios at Rhodes became so well known the tradition was established that this was simply the way things happened on the island-- and there was no reason to question it. That conclusion, combined with the intense heat and the full view of the sun's daily path on the highest promontory above their capital, may have been all the Rhodians needed to insist that their island was the home of Helios. Later, in the third century B.C., they would raise on the summit of Monte Smith the ultimate expression of their convictions: The Colossus of Rhodes.

\section{Postscript}

Figures P.1-3. An interesting comparison. Hungary's impressive bronze "Freedom Statue", standing high above the Danube River in central Budapest today, perhaps provides a close contemporary parallel to the ancient geographical setting for the Colossus of Rhodes. While not on an island, not on the sea, and not old, it, nonetheless, rests solidly on a limestone composite (dolomite) promontory called the Citadel (Gellért Hill), from which a view of the capital can be seen from all around. It is immediately adjacent to the old city fort atop the hill, a situation not unlike what we have proposed for the Colossus on Monte Smith, and, in its case, the 131-foot statue in Figure P.2 (pedestal 85 feet; statue 46 feet) views all river traffic coming and going from Budapest (Figure P.3). It is the most prominent feature of the entire cityscape, and another case of why the highest, most visible points (especially those above important water lanes) have for centuries been chosen as sites of sacred importance and defense. There must always have been a forerunner here, a light tower to dispatch and receive messages, warn of danger, and inform vessels on the river of their approach and departure from Budapest-- especially 
in combination with a fortress or defensive walls. This particular "Statue of Liberty" was ironically raised by Soviet occupiers in 1947 to celebrate their "liberation" of Hungary. The Colossus of Rhodes was around 160 feet high, including its pedestal.

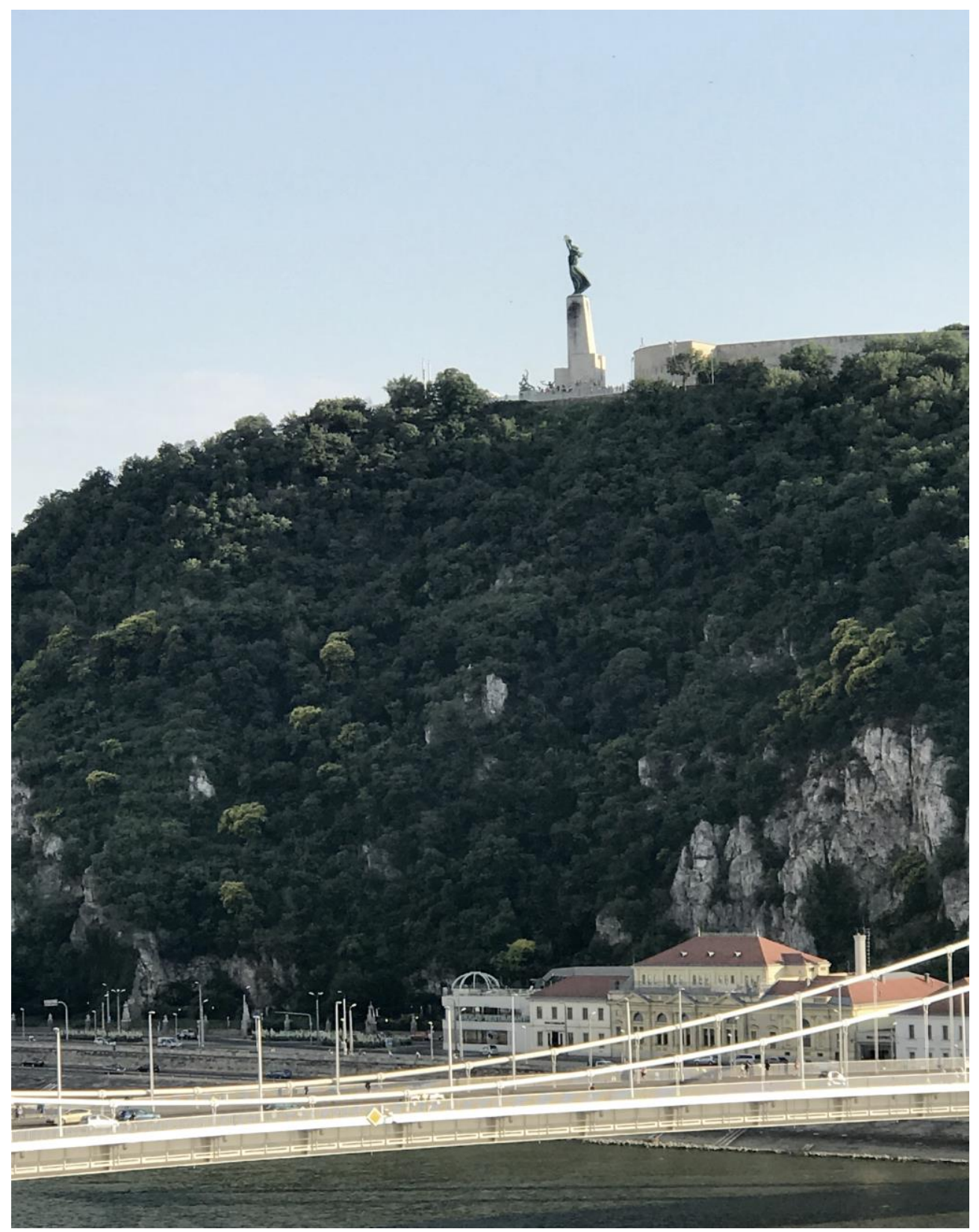

Figure P1. 
Vol. 5, No. 2

Kebric: The Colossus of Rhodes: Some Observations ...
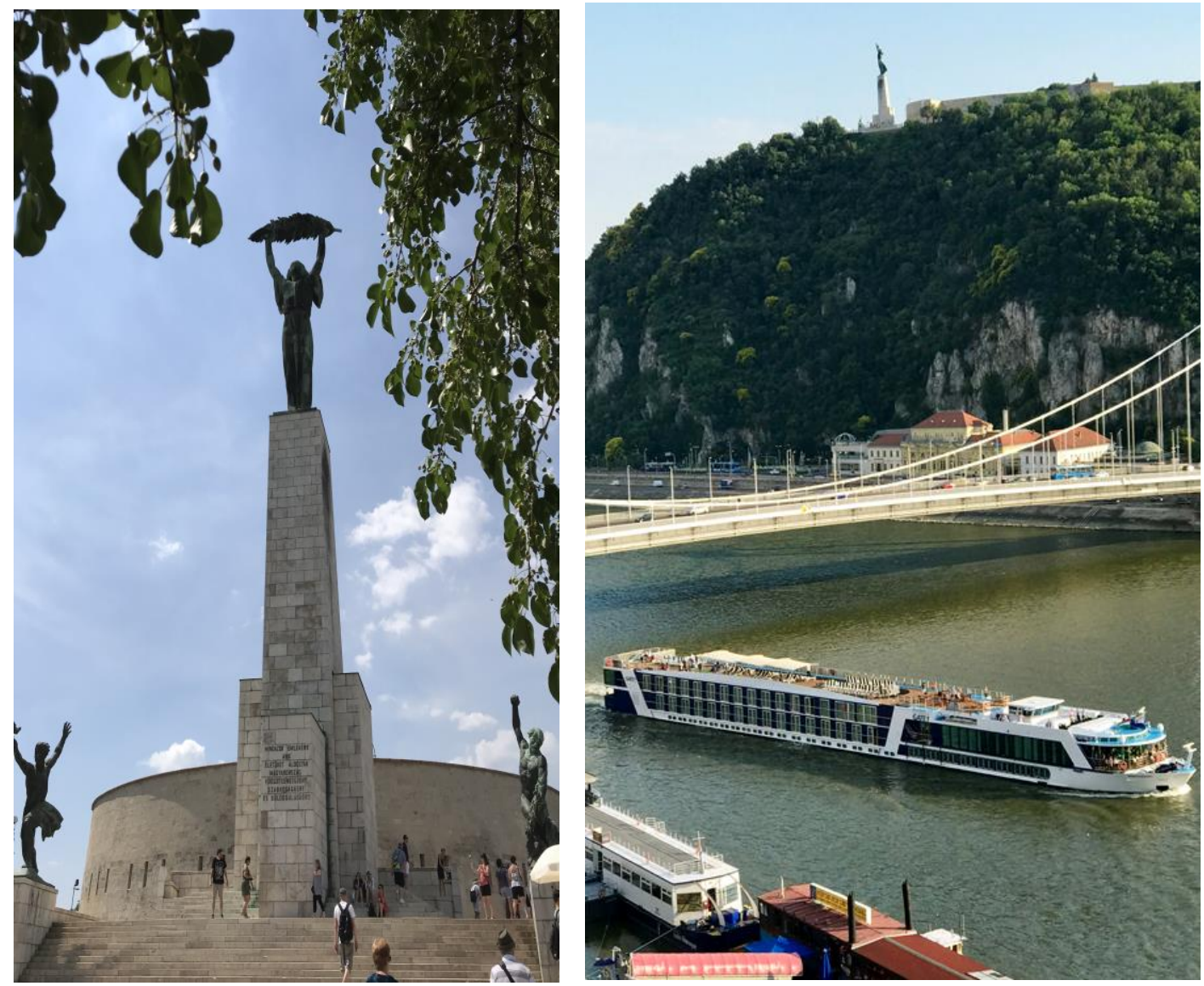

Figure P2.

Figure P3.

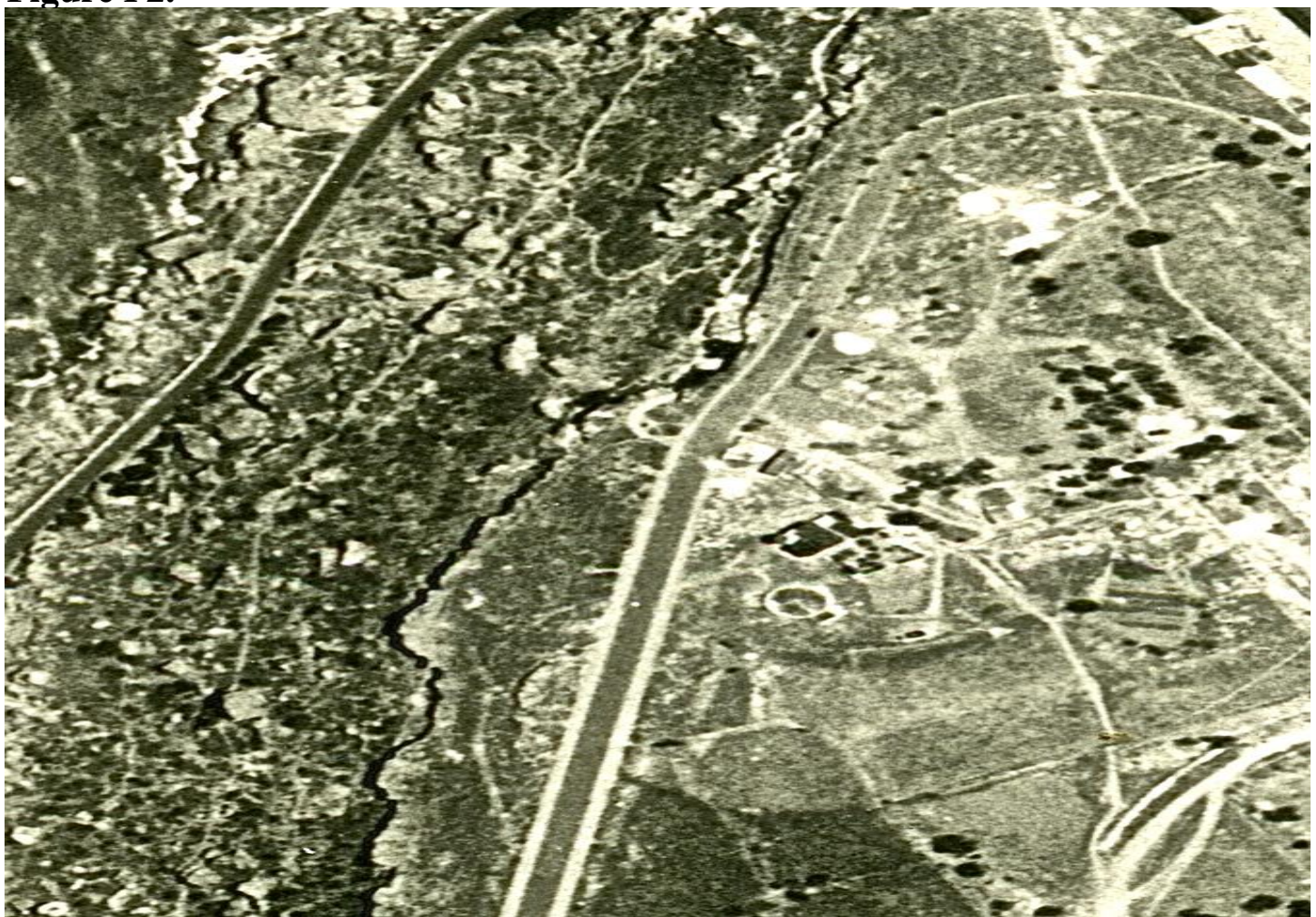


Curator. There are numerous signs of "human activity" at the time on the western side of Monte Smith, down its slopes to the road by the sea. When this photo is compared to recent satillete image of the same area below in Figure N.2.

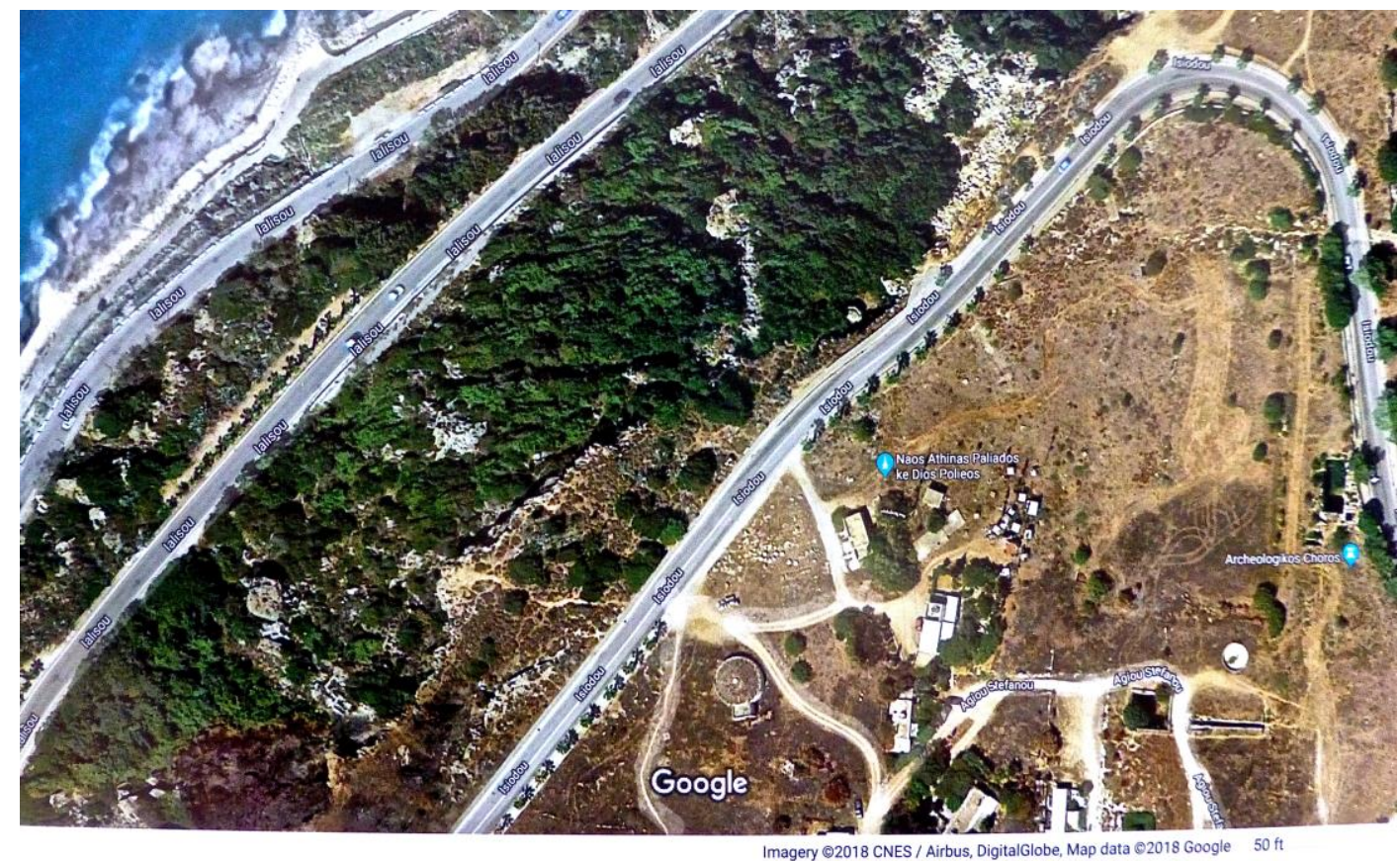

Figure N.2. Figure N.2., it is clear that the limestone shelf at the top of Monte Smith has detriorated during just the past seven decades. Earthquakes are still frequent. Two-thousand- three- hundredyears ago, the shelf must have extended further out toward the sea-- and whatever remains from the time of the Colossus, perhaps even including evidence regarding it, would have disappeared centuries ago. In Figure N.1 above, a large dark, presumably Italian military complex is visible to the right of the middle road in the center of the picture. It would have mostly covered the site of the great Temple of Athena and Zeus (indicated in N.2) at the summit of Monte Smith. The "fort" no longer exists, but the circular building immedidately below it, perhaps for ammunition storage, is still there and can be seen in both photos. There has been so much building up and tearing down activity in the area over the millenia (as well as war damage) that discovering anything identifiable there for our purposes has been impossible. It was somewhere in this once sacred spot that we believe the Colossus of Rhodes had stood. 


\section{Bibliography}

Ancient

Beckby, Hermann, ed., Anthologia Graeca. Munich, 1957.

Geer, Russel M., Diodorus, History. Loeb Classical Library. Cambridge, Mass.: Harvard University Press, 1947.

Schlesinger, Alfred C., Livy, History of Rome. Loeb Classical Library. Cambridge, Mass: Harvard University Press, 1951 (Reprint, 1989).

Rackham, H., Pliny, Natural History. Loeb Classical Library. Cambridge, Mass: Harvard University Press, 1952 (Reprint, 1995).

Paton, W.R., Polybius, Histories. Loeb Classical Library. Cambridge, Mass.: Harvard University Press, 1927.

Austin, C. and Bastianini, G., eds. Posidippi Pellaei Quae Supersunt Omnia. Milan, 2002.

Modern

Badian, Ernst. Foreign Clientelae (264-70 B.C.). Oxford: Oxford University Press, [reprint] 1972.

Berthold, Richard. Rhodes in the Hellenistic Age. Ithaca, New York: Cornell University Press, 2009.

Cook, Arthur B. Zeus: A Study in Ancient Religion (Band 1). Cambridge: Cambridge University Press, 1914.

Graves, Robert. The Greek Myths. Volume 2. Baltimore: Penguin Books, 1966.

Kebric R.B. The Colossus of Rhodes: Its Height and Pedestal. Athens Journal of Humanities and Arts (2019a) [forthcoming].

Kebric R.B. Lighting the Colossus of Rhodes: A Beacon by Day and Night. Athens Journal of Mediterranean Studies, 5, no 1(2019b): 11-32.

Schipporeit, Sven. "The New Order of Time and Cult in Synoecized Poleis," Center for Hellenic Studies Research Bulletin (CHS) 4, no.2 (2016). http://nrs.harvard.edu.

Vedder, Ursula. "Was the Colossus of Rhodes Cast in Courses or in Large Sections?" in Artistry in Bronze: The Greeks and Their Legacy. XIXth International Congress on Ancient Bronzes. Edited by Jens M. Daehner, Kenneth Lapatin, and Ambra Spinelli. The J. Paul Getty Museum and the Getty Conservation Institute, Los Angeles, October, 2015, www.getty.edu/publications/artistryinbronze/largescale-bronzes/2-vedder/.

Walbank, Frank W. A Historical Commentary on Polybius, Volume III. Oxford: Oxford University Press, 1967. Special Edition for Sandpiper Books, Ltd., 1999. 